\title{
Collaboration Between Firms and Universities in Italy: The Role of a Firm's Proximity to Top-Rated Departments
}

\author{
Davide Fantino · Alessandra Mori • Diego Scalise
}

Received: 23 September 2013 / Accepted: 14 March 2014 / Published online: 3 December 2014

(C) Società Italiana degli Economisti (Italian Economic Association) 2014

\begin{abstract}
This work aims at examining the determinants of research collaboration between firms and universities using the results of the 15th wave of the Bank of Italy Business Outlook Survey on Firms, together with data on the quality and the importance of university research. The distance from top research centres is the most important factor in determining the probability of collaboration. The presence of different innovation sources increases the probability of collaboration; proximity is more important for small- and medium-sized firms, while larger ones collaborate with universities better able to sell the results of their research, regardless of their location.
\end{abstract}

Keywords Research collaboration · Innovation · R\&D expenditure · Technology transfer

JEL Classification $\quad \mathrm{L} 24 \cdot \mathrm{O} 31 \cdot \mathrm{O} 32 \cdot \mathrm{R} 12$

The opinions expressed in this paper are those of the authors and do not necessarily represent those of the
Bank of Italy. We thank A. Accetturo, F. Ballio, G. de Blasio, M. E. Bontempi, C. Menon, P. Rossi, M.
Sbracia, two anonymous referees and participants at the Bank of Italy-Bologna University Workshop "Le
trasformazioni dei sistemi produttivi locali" for comments and suggestions. We also thank P. Natile and P.
Santopadre for their excellent research assistantship. Any errors are the responsibility of the authors alone.

D. Fantino $(\varangle)$

Economic Outlook and Monetary Policy Department, Bank of Italy,

Via Nazionale 91, 00184 Rome, Italy

e-mail: davide.fantino@bancaditalia.it

A. Mori · D. Scalise

Economic Research Unit, Bank of Italy, Milan Branch, Milan, Italy 


\section{Introduction and Main Results}

Empirical evidence on research and innovation gives a peculiar and somewhat worrying picture for Italy: R\&D expenditure, already low by international standards, has not been growing significantly. In 2010 it represented 1.26\% of GDP; it was 1.05 in 1998. The UE27 average was around $2 \%$, with values of more than $2.5 \%$ for Northern European countries. Firms' share, usually the most dynamic component, is around $50 \%$, against values of more than 60 and sometimes $70 \%$ recorded in other European countries (Istat, Eurostat, various years). In addition, Italian firms tend to take out only a small number of patents compared with their international peers. The literature has proposed various explanatory factors, such as the prevalent orientation toward traditional sectors and the relatively small size of Italian firms, which makes financing of internal research difficult for them (see Rossi 2006; Bugamelli et al. 2012). Some scholars defined this informal and non certified system as "researchless innovation" (Bonaccorsi and Granelli 2005; Kleinknecht 1987), a model that has suffered from the introduction of new technologies and from the competition of emerging countries in international markets.

However some non-internal innovation sources are available to firms, through interactions with universities and public research centres. In general universities improve the creation of human and social capital and stimulate innovative ideas in the local communities through teaching and basic research. Previous studies have found a positive relationship between basic academic research and local innovation outcomes thanks to the effects of knowledge spillovers (Arrow 1962; Nelson 1986; Jaffe 1989) and the location of firms on growth (Varga 2000; Bade and Nerlinger 2000; Abramovsky et al. 2007). Sometimes knowledge transfers between university and economic agents are formalized in a relationship of collaboration, with the aim of improving the commercialization of research, reducing distortions coming from the public good nature of academic output and exploiting the tacit knowledge of the academic researchers. This collaboration, together with the creation of human and social capital, can become a strong driver of local development (Breznitz and Feldman 2012; Feller and Feldman 2010; Bercovitz and Feldman 2006). Hence it is crucial, both in normative and positive terms, to understand the factors that facilitate knowledge transfer from universities to firms. "How important is geographical proximity? What is the role of the quality of research supplied by universities? What is the importance of informal interactions between public and private researchers?" are some of the questions that empirical research has tried to address.

In this paper we examine the determinants of research collaboration between firms and universities or public research centres in Italy in 2005-2007, using the results of the 15th wave of the Bank of Italy Business Outlook Survey on Industrial and Service Firms (hereinafter, "Banca d'Italia 2007") conducted on a sample of about 3,000 industrial and 1,000 non-financial services firms with at least 20 employees.

We estimate a multivariate probit model for the probability of firm/university collaboration. The main determinant is the geographic proximity of the firm to a top-rated university in subjects considered important to the industry to which the firm belongs. Other determinants include the importance of different innovation sources, together with firm, sector and region controls. In order to evaluate research quality we used the 
ranking provided by the Triennial Evaluation Research Project (VTR), conducted by the Italian Ministry of Education, Universities and Research in 2006 (MIUR 2006) on different indicators. This was merged with the Carnegie Mellon Survey (CMS Cohen et al. 2002), developed in 1994, which quantifies the importance of ten research fields for various manufacturing sectors in the USA. Through the CMS we paired each firm with the most important subjects for its own sector, and through the VTR we singled out the best departments for each subject in Italy, checking for firm/department geographic distance.

The main result is that the likelihood of being involved in research collaboration is positively correlated to the firm's proximity to a high quality university. Physical proximity to any generic university does not increase the probability of collaboration. Other results indicate that the presence of different innovation sources increases the probability of collaboration. Proximity is more important for small and medium firms, while large ones collaborate with universities that are better able to sell the results of their research, regardless of location.

The empirical literature has suggested a number of variables to explain the probability of collaboration between firms and universities. Our analysis focuses on the importance of geographical proximity (Thune 2006), where distance can be interpreted as a proxy for the effects of informal interactions between public and private researchers, which are crucial in determining the occurrence of collaboration agreements. Proximity can make these contacts easier and more fruitful ("complex interactions" in Polanyi 1969; "tacit knowledge" in Lundvall 1992), or can be a proxy for "communication distance" (Gertler 2005), which is determined by social and cultural factors, in addition to technological ones.

We also focus on the importance of the quality of research. In the empirical literature distance has been paired with research quality. Mansfield and Lee (1996) find that distance and quality of research are the main determinants for the share of academic research financed by firms (based on a sample of US firms in different sectors). Abramovsky and Simpson (2008) use CIS (Community Innovation Survey) data on knowledge transfers from universities to innovative firms in the UK. They show that $\mathrm{R} \& \mathrm{D}$ offices tend to be concentrated near top-rated universities in subjects considered important for the sector to which the firm belongs, and that proximity is one of the main determinants of firm/university collaboration. This result is in line with the findings in Laursen et al. (2008) for the UK, in Rosa and Mohnen (2008) for Canada, and in Rasiah and Govindaraju (2009) for Malaysia.

We also take the firms' characteristics into account. According to some literature, the existence of informal interactions between public and private researchers can be inferred from firm size. Large firms are more likely to share a common ground of knowledge and relations with research centres (cognitive and social proximity, Boschma 2005) and to possess diversified skills that make them able to understand and make commercial use of the results of academic research (the concept of absorptive capacity, in Cohen and Levinthal 1990; see also Rothaermel and Thursby 2005; Buganza et al. 2007). Size therefore may foster research collaboration.

Lastly, we take into account the commercial policies of universities as a possible driver for collaboration. In many countries universities have long been active in adopting policies to promote the commercial exploitation of research results. This 


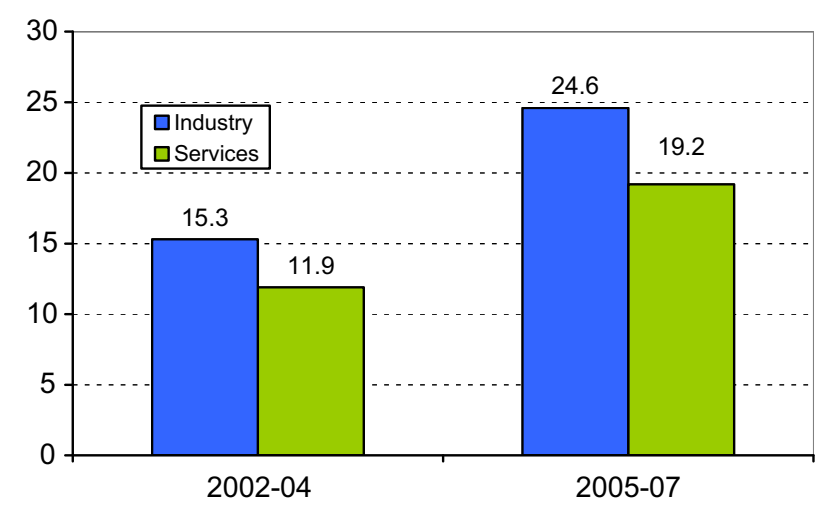

Fig. 1 Interactions between Italian firms and universities/public research centres over time (1) (percent; frequency of affirmative answers). Source Bank of Italy, Business Outlook Survey of Industrial and Service Firms. (1) Questions: 1. Has the firm entered into collaboration agreements with Italian universities (or public research centres) in the period 2002-2004? And in the period 2005-2007? Weighted by the population of firms and normalized with the number of valid answers

phenomenon is increasing in Italy as well (Pietrabissa and Conti 2005; Piccaluga and Balderi 2006; CRUI 2007; Netval 2006). Empirical evidence suggests that universities promote partnerships with firms in order to ease their budget constraints and to improve their own efficiency, both in teaching and in research (Breno et al. 2002, Bonaccorsi and Granelli 2005). The theory does not have a strong a priori on the effect of commercial orientation of universities on research collaboration, although it can facilitate the production of knowledge with a commercial value (Di Gregorio and Shane 2003), or it may inhibit technology transfer, in the interest of the sponsoring companies, to protect the results of patented research and increase the sponsors' market power (as in Colombo et al. 2010).

The rest of the paper is structured as follows: Section 2 describes interactions between Italian firms and universities, Sect. 3 presents an econometric analysis of the determinants of the probability of collaboration with universities and robustness checks. Section 4 concludes. In the Appendix we provide some information on the universities' budgets, commercial orientation and academic spin-offs.

\section{Interactions Between Firms and Universities: A Description}

According to Banca d'Italia (2007), in 2005-2007 some $22.3 \%$ of Italian firms had some interaction with universities or research centres (Fig. 1).

One fourth $(25.4 \%)$ of the firms which had a relationship with universities collaborated in joint research projects, almost half (42.3\%) purchased consultancy services, that could encompass technological solutions too, ${ }^{1}$ and $68.8 \%$ hosted internship stu-

\footnotetext{
1 Consulting services, when they are provided by a university department or a public research centre, may be seen either as a form of extramural R\&D, or as a weak form of research collaboration (Katz and Martin 1997) and may imply technology transfer (defined as the intentional but not free process of making technological developments accessible to a wider range of users for further exploitation).
} 
dents (Tables 1, 2). Academic spin-offs, i.e. direct business ventures with academic researchers, are not widespread in Italy. ${ }^{2}$

Firm size may foster interactions (73.4 \% among larger industrial firms). Public grants do not seem correlated: in conducting projects with universities only $12.7 \%$ of firms received tax subsidies and $24.8 \%$ qualified for public funding, including EU financing (Table 1).

Interactions with academia have grown in time: in 2005-2007 the share of firms involved was almost twice as much as during the previous 3 years. Once established, the relationship is persistent: $83.1 \%$ of the firms that interacted with universities in 2002-2004 continued to do so in the next 3 years.

Internships often constitute the training period for skilled labour, obtained at low cost, and do not imply any research collaboration. For this reason Fig. 2 shows cases of research collaboration in 2005-2007 excluding those in which the firm limited itself to hosting interns when the average frequency decreased by about a half (13.1\%).

This variable, which excludes hosting interns but includes the purchase of consulting services, is the one that will be used in Sect. 3 on the determinants of the probability of research collaboration.

Although the phenomenon of collaboration is not negligible, the majority of Italian firms have no interactions at all with universities (Table 3). Figure 3 shows the distribution of the reasons reported by firms: the main obstacle is lack of interest $(54.3 \%)$, but also a widespread perception that academic research is not suitable for business use $(33.3 \%)$. Low quality, high costs, bureaucracy or a preference for foreign research centres are felt as less important. Among firms that did not renew collaboration, the frequency of those who consider it too expensive increased.

\section{The Determinants of Collaboration with Universities: Econometric Analysis}

\subsection{Univariate Analysis and Data}

In this section we provide some descriptive analysis for factors that may influence research collaboration. The variable of interest, collab $_{i}$, is the probability that the $i$-th firm had some form of research collaboration with a university/public research centre in 2005-2007, excluding the cases in which the firm only hosted internships and including the purchase of consulting services.

The firm's proximity to a generic university, regardless of quality or subject, is proxied by a dummy variable that takes the value of 1 if any university is located within $10 \mathrm{~km}$ from the firm.

The firm's proximity to top-rated universities in important subjects is measured by a dummy variable that takes the value of 1 if one of the two best performing departments in fields considered the most important by the firm is located within a $10 \mathrm{~km}$ range from the firm itself.

\footnotetext{
2 See Appendix.
} 


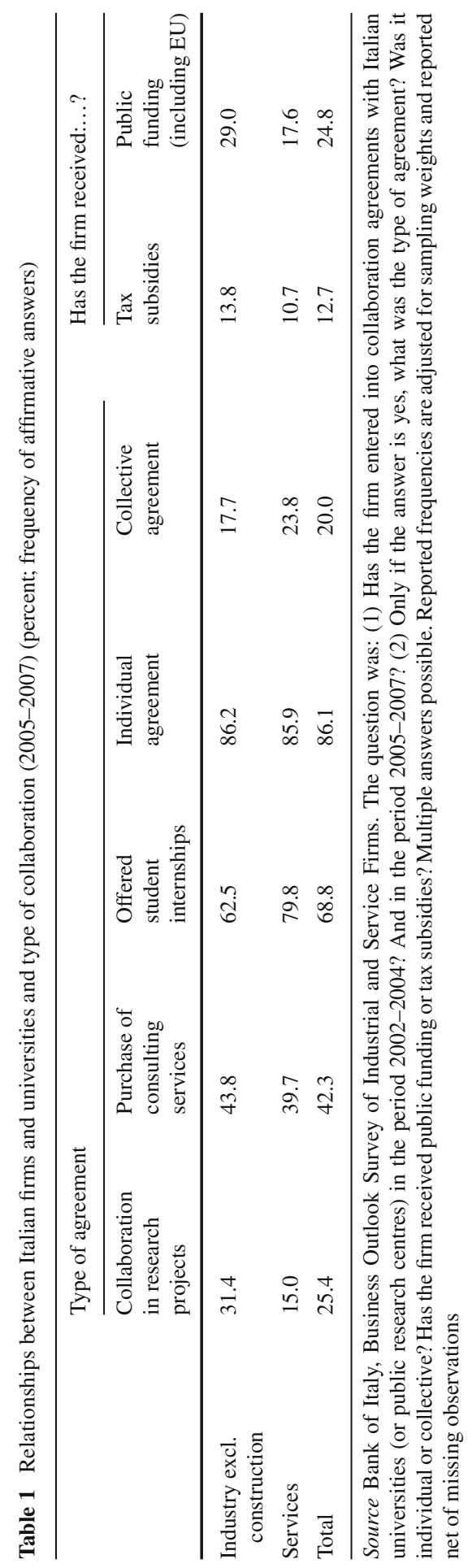




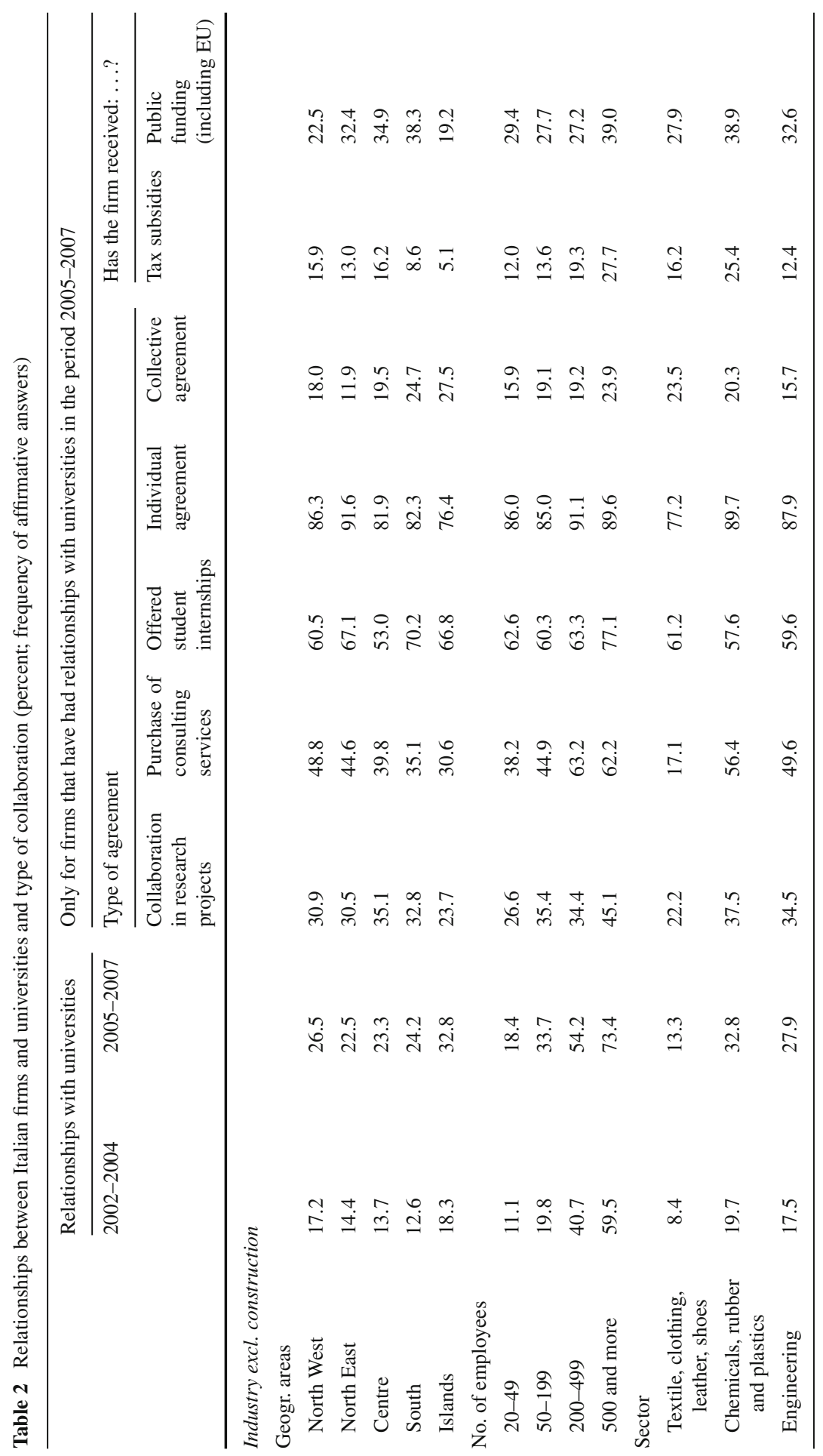




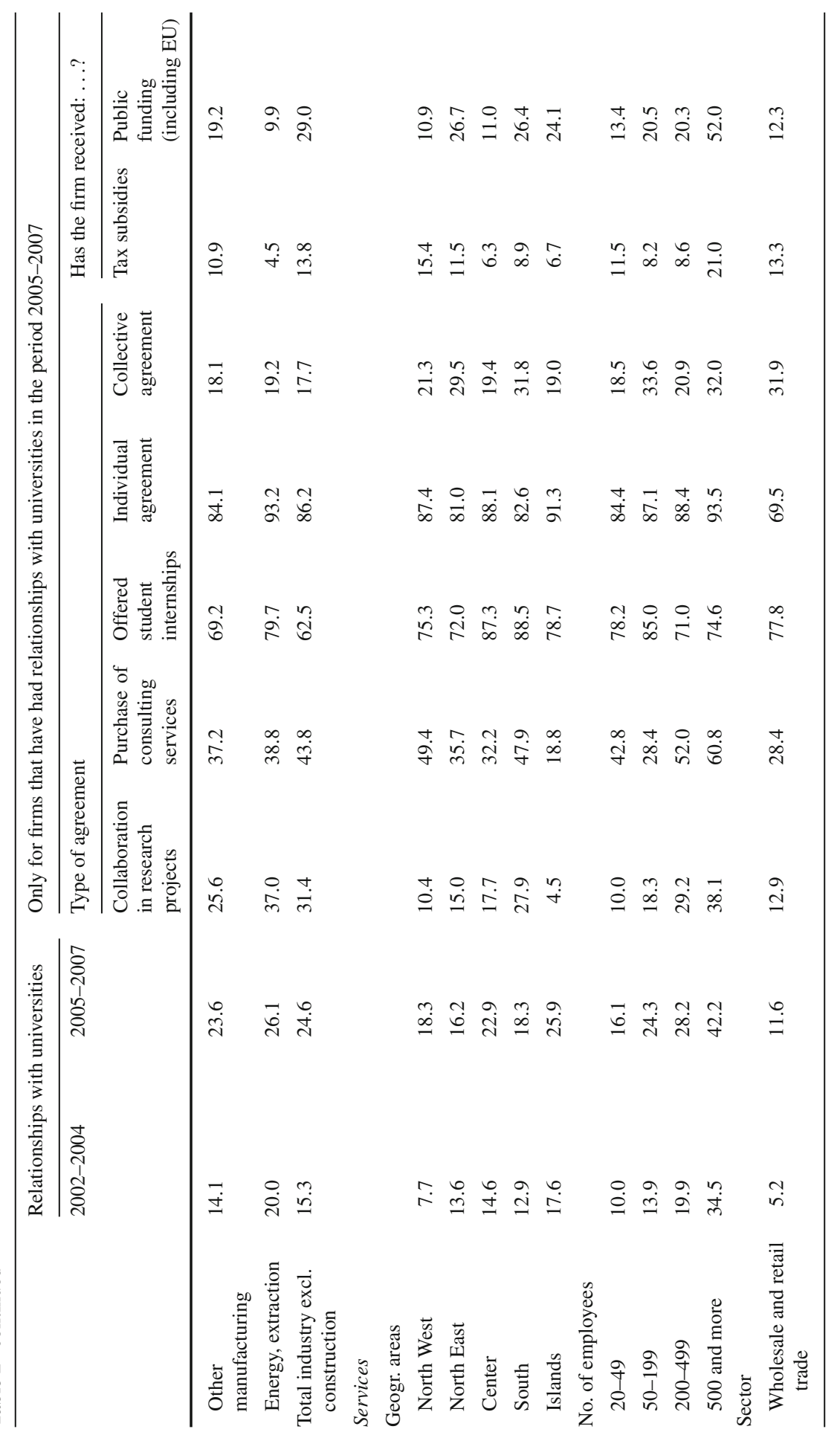




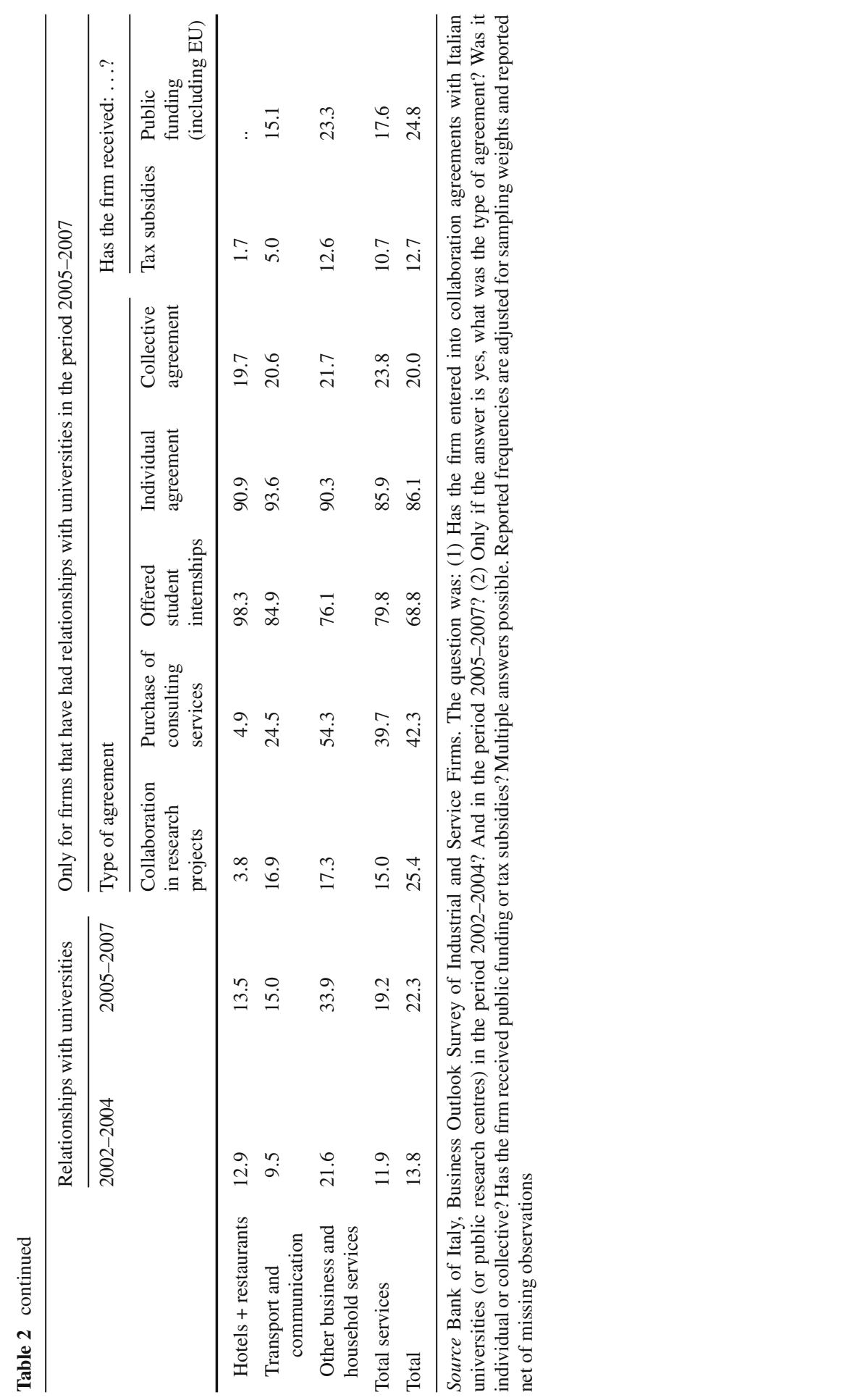




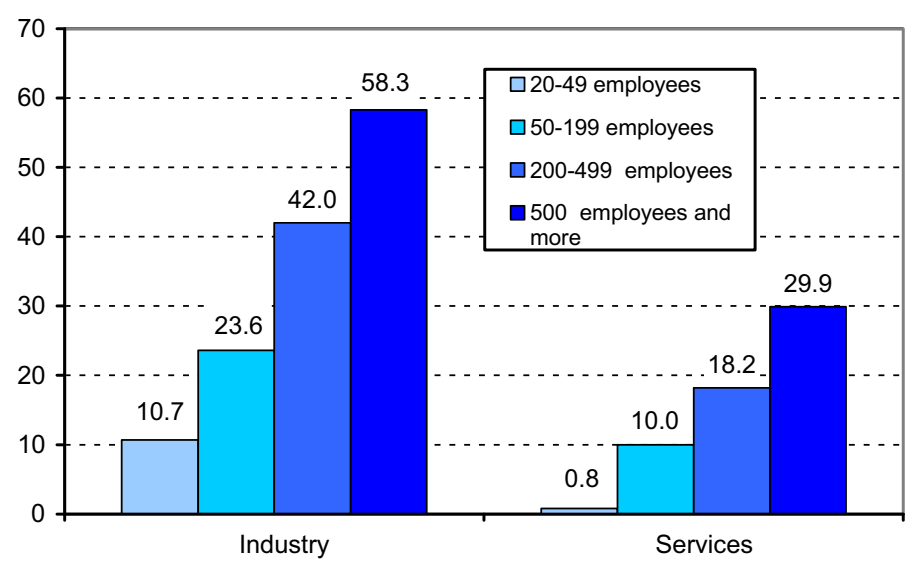

Fig. 2 Interactions aimed to research collaboration 2005-2007 (percent; frequency of affirmative answers). Source Bank of Italy, Business Outlook Survey of Industrial and Service Firms. Questions: 1. Has the firm entered into collaboration agreements with Italian universities (or public research centres) in the period 2005-2007? 2. Only if the answer is no, why not? (a) the idea has never been considered (b) academic research is unrelated to the firm's requirements (c) universities involve too much bureaucracy (d) the quality of research is unsatisfactory (e) the cost is too high (f) the firm prefers to work with foreign universities (g) other. Weighted by the population of firms and normalized with the number of valid answers

Department ranking comes from the National Triennial Research Evaluation exercise in 2001-2003 (VTR, in MIUR 2006), currently the only one available, originally envisaged to distribute state funds to universities and research centres. ${ }^{3}$

The importance of a particular scientific field for firms in any industry is stated using the Carnegie Mellon Survey (1994): this lists the importance of ten technical subjects in the opinion of R\&D managers of different manufacturing industries in the United States. ${ }^{4}$ Following Abramovsky and Simpson (2008), we define "important subjects" as the two most important ones according to the CMS, provided that they have been judged as "important" or "very important" by at least $50 \%$ of the sample. To reconcile the data from the CMS to those from VTR, some subjects were merged. ${ }^{5}$

\footnotetext{
${ }^{3}$ Each of the 102 involved centres selected a fixed number of research products (books, journal articles, patents and so on) and sent them to one of the 20 expert panels for evaluation. Each product was evaluated by at least two independent experts, who produced six different rankings for each subject according to different indicators: quality, property rights, international mobility, advanced training, ability to attract financial resources, and ability in using available funds (MIUR 2006 for details). In our analysis we use Indicator A (quality of products), as we focus on the quality of research and not on the quality of teaching. Best performers are defined as the first two departments in Italy among "mega-centres", "normal centres" and "small centres".

4 The CMS is based on interviews with managers of the R\&D departments of manufacturing companies located in the United States. They were asked to evaluate the importance of research in any field for their innovation activities. Subjects are: biology, chemistry, physics, computer science, materials science, medicine, mechanical engineering, electronics, chemistry and mathematics. See Cohen et al. (2002) for a complete description.

${ }^{5}$ Computer science was merged with mathematics; all branches of engineering (chemical, mechanical and electronic) were grouped under "Industrial Engineering and Information"; materials science was not included in the VTR and therefore was not used in the empirical analysis.
} 


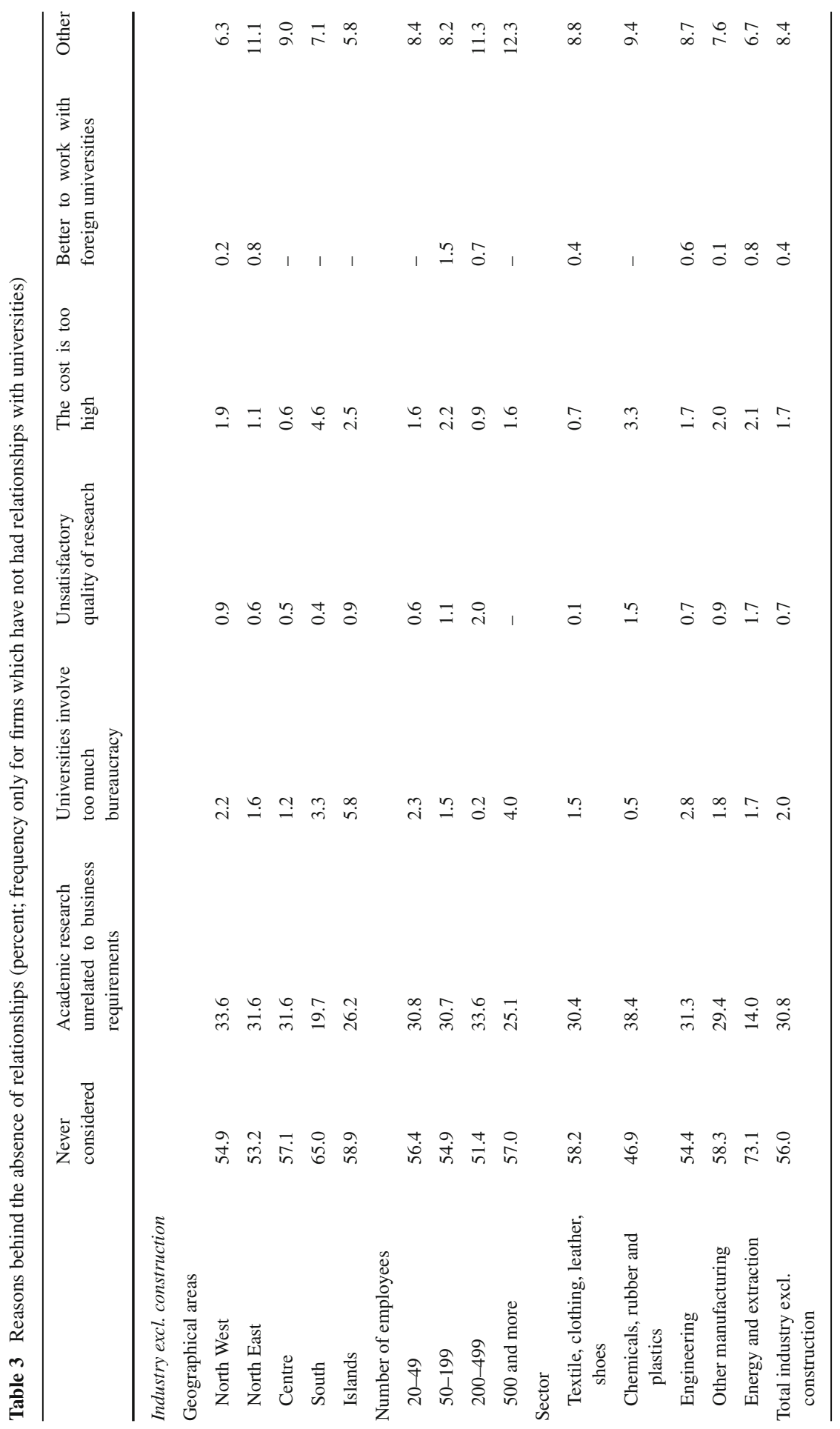




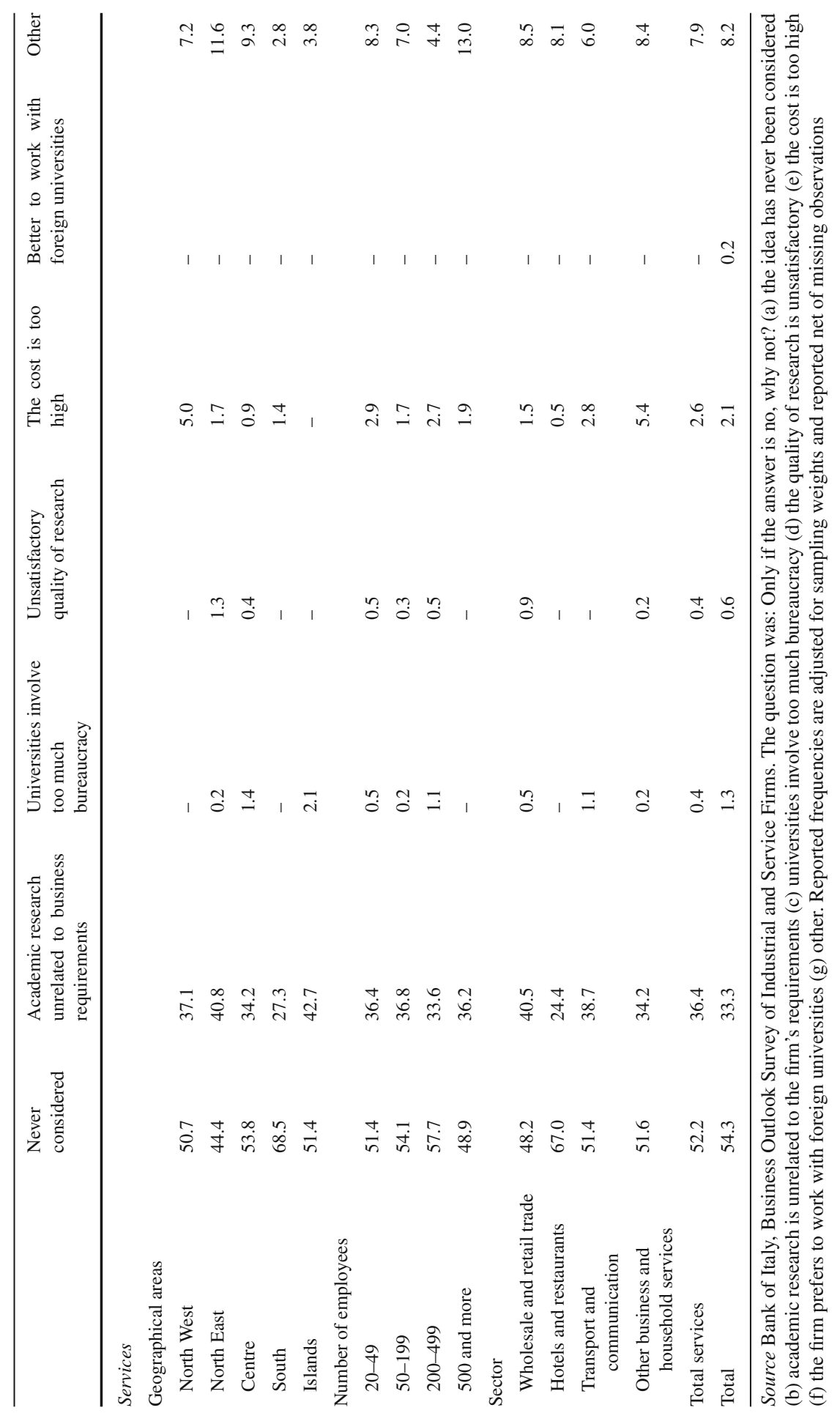




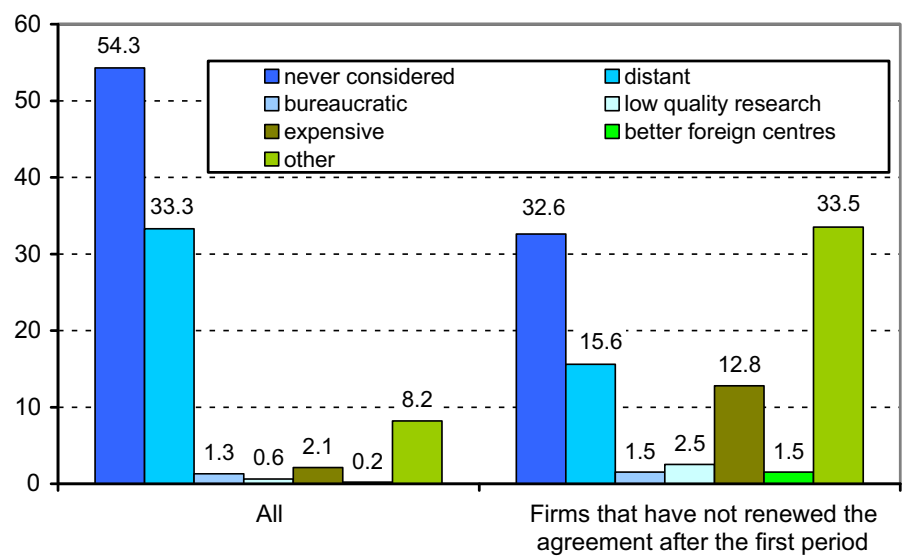

Fig. 3 Reasons behind the absence of interactions (percent; frequency of affirmative answers). Source Bank of Italy, Business Outlook Survey of Industrial and Service Firms. Questions: 1. Has the firm entered into collaboration agreements with Italian universities (or public research centres) in the period 20052007? 2. Only if the answer is no, why not? (a) the idea has never been considered (b) academic research is unrelated to the firm's requirements (c) universities involve too much bureaucracy (d) the quality of research is unsatisfactory (e) the cost is too high (f) the firm prefers to work with foreign universities (g) other. Weighted by the population of firms and normalized with the number of valid answers

In general engineering and mathematics/computer science turn out to be the most important subjects for all sectors apart from chemicals, rubber and plastics, for which chemistry is the second most important field. ${ }^{6}$

Other variables used in the analysis refer to the characteristics of firms (Banca d'Italia 2007), and include: size (measured as the log average workforce in 2006); dummy variables to check for the presence of an in-house research centre in Italy or abroad and for the acquisition of a patent, software or innovative machinery in 20052007; the degree of importance attributed to different innovation sources: suppliers, private consultancies, universities, public research centres; the incidence of software expenditure in fixed investments and of exports in sales in 2006.

Bivariate tables (Table 4) show that what seems to matter for academic collaboration is proximity to top-rated departments in important fields, rather than to a generic university. The percentage of firms entering into a collaboration with a university is significantly higher (almost double) for those close to high quality departments than for distant ones. However, the effect of being close to a generic university seems much weaker. Moreover, firms which purchased patents in the period 2005-2007 displayed a much higher propensity to enter into collaboration with universities.

We measure the commercial orientation of a university by the presence of a Technology Transfer Office (TTO), detected from the websites of universities and double-checked by telephone. The variable takes the value of 1 if the office is oper-

\footnotetext{
6 In the pooled regressions (see infra) we made an exception and included chemistry (third in the CMS ranking but with a score of $33.7 \%$ ) in order to evaluate the effects of wider scientific research on the whole sample, which includes service companies not covered by the CMS. Chemistry, though, scores higher than $50 \%$ in many sub-sectors. Results are robust regardless of whether chemistry is included or excluded.
} 
Table 4 Bivariate tables (percent; frequencies)

\begin{tabular}{|c|c|c|c|}
\hline The firm had research collaboration & No & Yes & Total \\
\hline \multicolumn{4}{|c|}{ University located within $10 \mathrm{~km}$ range from the firm } \\
\hline No & 83.9 & 76.2 & 79.3 \\
\hline Yes & 16.1 & 23.8 & 20.7 \\
\hline Total $^{\mathrm{a}}$ & 100 & 100 & 100 \\
\hline \multicolumn{4}{|c|}{ Top-rated departments in important subjects located within $10 \mathrm{~km}$ range from the firm } \\
\hline No & 81.4 & 67.2 & 79.3 \\
\hline Yes & 18.6 & 32.8 & 20.7 \\
\hline Total $^{\mathrm{a}}$ & 100 & 100 & 100 \\
\hline \multicolumn{4}{|l|}{ Purchase of patents } \\
\hline No & 81.8 & 54.9 & 79.1 \\
\hline Yes & 18.2 & 45.1 & 20.7 \\
\hline Total $^{\mathrm{a}}$ & 100 & 100 & 100 \\
\hline
\end{tabular}

a Totals may not sum up to 100 due to rounding error

ational and 0 otherwise. Variables also include: a dummy equal to 1 if the firm is located in an industrial district (according to the Sforzi-Istat definition, not necessarily with the same productive specialization) or inside a science park; the number of firms with more than 20 employees in the region (Census source); and sector, region and macroarea controls. Descriptive statistics for the main variables in the analysis are reported in Table 5. For a complete definition of all variables see Table 6.

\subsection{Multivariate Analysis}

In this section we present the results of a multivariate probit analysis on the determinants of the probability that the firm had some form of research collaboration with a university/public research centre in 2005-2007, excluding the cases in which the firm has only hosted internships ${ }^{7}$ and including the purchase of consulting services.

This analysis aims to give an answer to some of the questions that emerge from the literature review:

- Is the probability of collaboration influenced by the proximity of the firm to top quality academic research centres?

- Is the probability of collaboration influenced by the presence of other sources of innovation?

\footnotetext{
${ }^{7}$ Hosting internships per se is not a good proxy to measure collaboration. However, it is surprising that the willingness to host skilled labour never has explanatory power in any regression (results available upon request).
} 
Table 5 Descriptive statistics

\begin{tabular}{lllrrr}
\hline Main variables & Observations & Mean & SD & Min & Max \\
\hline Collab & 4,164 & 0.2 & 0.4 & 0 & 1 \\
Top engineering...dept. $<10 \mathrm{~km}$ & 4,196 & 0.2 & 0.4 & 0 & 1 \\
University dept. $<10 \mathrm{~km}$ & 4,196 & 0.6 & 0.5 & 0 & 1 \\
In (average workforce 2006) & 4,196 & 4.6 & 1.2 & 2 & 11 \\
Research centre in Italy & 4,185 & 0.3 & 0.5 & 0 & 1 \\
Research centre abroad & 4,170 & 0.1 & 0.2 & 0 & 1 \\
Suppliers & 3,897 & 0.9 & 1.0 & 0 & 3 \\
Private consultants & 3,893 & 0.9 & 1.1 & 0 & 3 \\
University & 3,979 & 0.5 & 0.9 & 0 & 3 \\
Purchase of patents (2005-2007) & 4,123 & 0.1 & 0.3 & 0 & 1 \\
Purchase of software and/or innovative machinery & 4,137 & 0.6 & 0.5 & 0 & 1 \\
Investment in software/investments & 3,340 & 0.2 & 1.4 & 0 & 1 \\
District & 4,196 & 0.3 & 0.4 & 0 & 1 \\
Average distance from top & 4,196 & 376 & 177 & 206 & 890 \\
Average distance from humanities & 4,196 & 368 & 140 & 160 & 850 \\
TTO density in the region & 4,196 & 2.7 & 1.7 & 0 & 6 \\
\hline
\end{tabular}

The maximum likelihood function for the probit model (Greene 1993) has the following shape:

$$
L n L=\sum_{i \in S} w_{i} \ln \Phi\left(x_{i} b\right)+\sum_{i \notin S} w_{i} \ln \left[1-\Phi\left(x_{i} b\right)\right]
$$

where $\Phi$ is the normal distribution; $\mathrm{S}$ is the set of observations collab $b_{i}$ different from zero, where colla $_{i}$ represents the research collaboration for the i-th firm; $w_{i}$ are sample weights given by the inverse of the probability that the i-th observation is included in the sample design; $x_{i}$ is a vector of individual characteristics of the firm, territorial and sector controls, as described above. We employ the robust Huber/White/Sandwich estimator for the variances.

\subsection{Results}

Table 7 shows the results for the probit estimation of the probability that the firm had some form of research collaboration with a university/public research centre in 20052007; the main determinants are distance from universities and quality of academic research; controls include firm's characteristics, sector dummies (column [1]), regional dummies (column [2]) or macroarea dummies (column [3]). The sample was then partitioned by size (Table 8) and sector (Table 9). Results are robust to different specifications (Table 7). 
Table 6 Dependent and explanatory variables used in the regressions

\begin{tabular}{|c|c|}
\hline Interest variables & Definition \\
\hline Collab & $\begin{array}{l}\text { Dummy equal to } 1 \text { if the firm had some form of research } \\
\text { collaboration with a university/public research centre in } \\
\text { 2005-2007, excluding the cases in which the firm has only hosted } \\
\text { internships and including the purchase of consulting services }\end{array}$ \\
\hline University dept $<10 \mathrm{~km}$ & $\begin{array}{l}\text { Dummy equal to } 1 \text { if a university is located within } 10 \mathrm{~km} \text { range } \\
\text { from the firm }\end{array}$ \\
\hline Top engineering. . .dept $<10 \mathrm{~km}$ & $\begin{array}{l}\text { Dummy equal to } 1 \text { if one of the best two departments in Italy that } \\
\text { deal with the most important subjects for the firm is located } \\
\text { within } 10 \mathrm{~km} \text { range from the firm }\end{array}$ \\
\hline $\begin{array}{l}\text { Number of universities within } \\
10 \mathrm{~km}\end{array}$ & Number of top universities within $10 \mathrm{~km}$ range from the firm \\
\hline Average workforce & Log average workforce in 2006 \\
\hline Research centre in Italy & Dummy equal to 1 if a university has a research facility in Italy \\
\hline Research centre abroad & Dummy equal to 1 if a university has a research facility abroad \\
\hline Suppliers & Importance of suppliers as innovation source ( 0 to 3 ) \\
\hline Private consultants & Importance of private consultants as innovation source ( 0 to 3 ) \\
\hline University & Importance of universities as innovation source (0 to 3 ) \\
\hline Purchase of patents (2005-2007) & $\begin{array}{l}\text { Dummy equal to } 1 \text { if the firm has purchased a patent in the period } \\
\text { 2005-2007 }\end{array}$ \\
\hline $\begin{array}{l}\text { Purchase of software and/or } \\
\text { innovative machinery }\end{array}$ & $\begin{array}{l}\text { Dummy equal to } 1 \text { if the firm has purchased software or innovative } \\
\text { machinery in the period 2005-2007 }\end{array}$ \\
\hline $\begin{array}{l}\text { Investment in } \\
\text { software/investments }\end{array}$ & Investments in software/investments \\
\hline
\end{tabular}

Control variables Definition

\section{District}

Same sector district

Different sector district

TTO density in the region

Density of firms in the region

Average distance from top

Minimum distance from top

Average distance from humanities

Exports over sales

Investments in machinery in 2006

Science park
Dummy equal to 1 if the firm belongs to an economic district

Dummy equal to 1 if the firm belongs to an economic district of the same economic sector

Dummy equal to 1 if the firm belongs to an economic district of a different economic sector

Number of TTOs in the region

Number of firms with more than 20 employees in the region

Average distance from the best two departments that deal with the most important subjects for the firm

Minimum distance from the best two departments that deal with the most important subjects for the firm

Average distance from the best two departments that deal with humanities

Exports over total sales

Investments in machinery in 2006

Dummy equal to 1 if the firm is located in a province where a science park is active (source: APSTI) 
Table 7 Probability of academic collaboration (2005-2007)

\begin{tabular}{|c|c|c|c|c|c|c|c|c|c|}
\hline \multirow[t]{2}{*}{$\begin{array}{l}\text { Independent } \\
\text { variable }^{\mathrm{a}}\end{array}$} & \multicolumn{3}{|l|}{ [1] Base } & \multicolumn{3}{|c|}{$\begin{array}{l}\text { [2] With regional } \\
\text { dummies }\end{array}$} & \multicolumn{3}{|c|}{$\begin{array}{l}\text { [3] With macroarea } \\
\text { dummies }\end{array}$} \\
\hline & Coefficient & $\begin{array}{l}\text { Rob. } \\
\text { SE }\end{array}$ & Signif. ${ }^{b}$ & Coefficient & $\begin{array}{l}\text { Rob. } \\
\text { SE }\end{array}$ & Signif. ${ }^{b}$ & Coefficient & $\begin{array}{l}\text { Rob. } \\
\text { SE }\end{array}$ & Signif. \\
\hline $\begin{array}{l}\text { University dept. } \\
\quad<10 \mathrm{~km}\end{array}$ & -0.02 & 0.01 & & -0.02 & 0.01 & & -0.02 & 0.016 & \\
\hline $\begin{array}{l}\text { Top engineering, } \\
\text { math chem. } \\
\text { dept. }<10 \mathrm{~km}\end{array}$ & 0.043 & 0.023 & $* *$ & 0.088 & 0.034 & $* * *$ & 0.045 & 0.023 & $* *$ \\
\hline $\begin{array}{l}\text { Average } \\
\text { workforce } 2006 \\
(\log )\end{array}$ & 0.034 & 0.004 & $* * *$ & 0.034 & 0.004 & $* * *$ & 0.034 & 0.004 & $* * *$ \\
\hline $\begin{array}{l}\text { Research centre in } \\
\text { Italy }\end{array}$ & 0.055 & 0.016 & $* * *$ & 0.050 & 0.015 & $* * *$ & 0.054 & 0.016 & $* * *$ \\
\hline $\begin{array}{l}\text { Research centre } \\
\text { abroad }\end{array}$ & 0.036 & 0.037 & & 0.032 & 0.03 & & 0.037 & 0.038 & \\
\hline Suppliers & -0.013 & 0.006 & $* *$ & -0.012 & 0.006 & $* *$ & -0.012 & 0.006 & $* *$ \\
\hline $\begin{array}{l}\text { Private } \\
\text { consultants }\end{array}$ & -0.007 & 0.006 & & -0.008 & 0.005 & & -0.007 & 0.006 & \\
\hline University & 0.098 & 0.01 & $* * *$ & 0.092 & 0.010 & $* * *$ & 0.097 & 0.011 & $* * *$ \\
\hline $\begin{array}{l}\text { Purchase of } \\
\text { patents } \\
(2005-2007)\end{array}$ & 0.055 & 0.026 & $* *$ & 0.055 & 0.025 & $* * *$ & 0.054 & 0.026 & $* *$ \\
\hline $\begin{array}{l}\text { Purchase of } \\
\text { software and/or } \\
\text { innovative } \\
\text { machinery }\end{array}$ & 0.044 & 0.01 & $* * *$ & 0.043 & 0.012 & $* * *$ & 0.044 & 0.013 & $* * *$ \\
\hline $\begin{array}{l}\text { Investment in } \\
\text { software }\end{array}$ & 0.004 & 0.001 & $* * *$ & 0.003 & 0.001 & $* * *$ & 0.004 & 0.001 & $* * *$ \\
\hline District & 0.005 & 0.01 & & 0.011 & 0.017 & & 0.008 & 0.015 & \\
\hline Sector dummies & Yes & & & Yes & & & Yes & & \\
\hline $\begin{array}{c}\text { Macroarea } \\
\text { dummies }\end{array}$ & No & & & No & & & Yes & & \\
\hline $\begin{array}{l}\text { Regional } \\
\text { dummies }\end{array}$ & No & & & Yes & & & No & & \\
\hline Number of obs. & 3,102 & & & 3,102 & & & 3,102 & & \\
\hline Pseudo $\mathrm{R}^{2}$ & 0.394 & & & 0.410 & & & 0.396 & & \\
\hline $\begin{array}{l}\text { Wald } \chi^{2 \mathrm{~b}} \\
\text { testparm }\end{array}$ & 573.30 & & $* * *$ & 653.07 & & $* * *$ & 580.22 & & $* * *$ \\
\hline Linktest (hatsq) ${ }^{\mathrm{b}}$ & -0.002 & 0.004 & & -0.041 & 0.034 & & -0.002 & 0.004 & \\
\hline
\end{tabular}

Dependent variable: probability of collaboration (2005-2007), excluding internships; model: Max Likelihood Probit, marginal effects reported. Standard errors are calculated using the Huber/White/sandwich robust estimator

a For sector dummies the base is textiles; for macroarea dummies North West; for regional dummies Piedmont; regressions are weighted for sampling weights

b Stars indicate levels of significance: $1 \%(* * *) ; 5 \%(* *) ; 10 \%(*)$ 


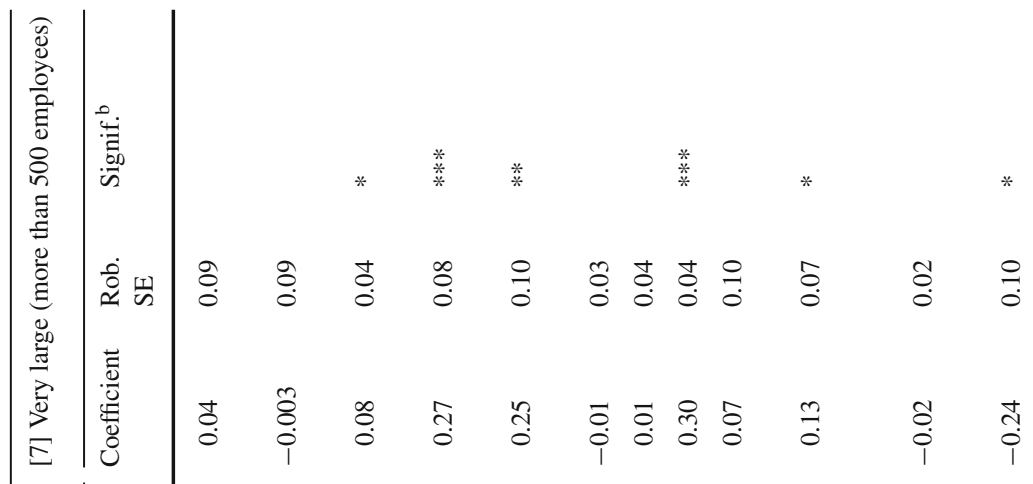

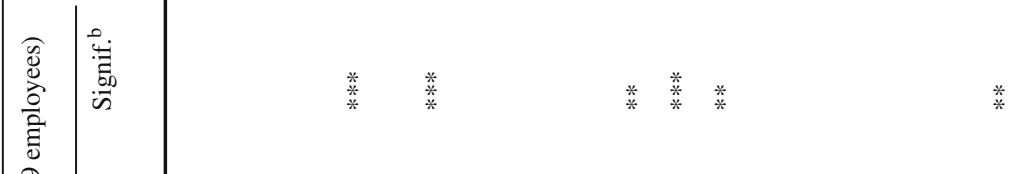

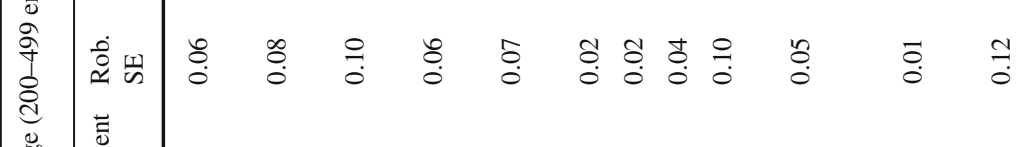

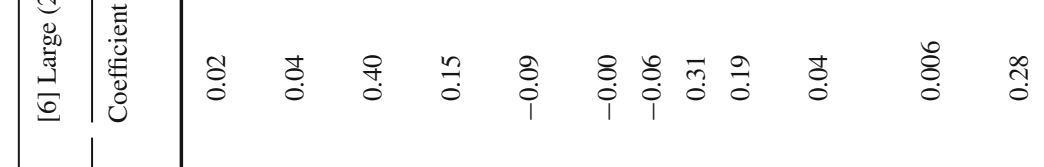

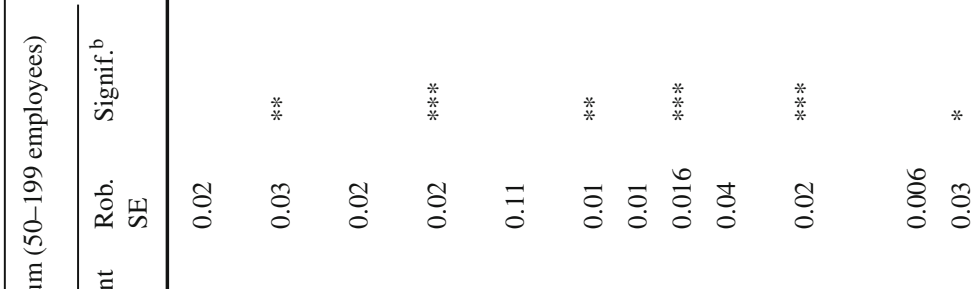

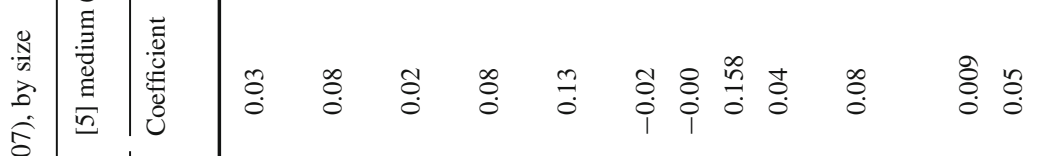

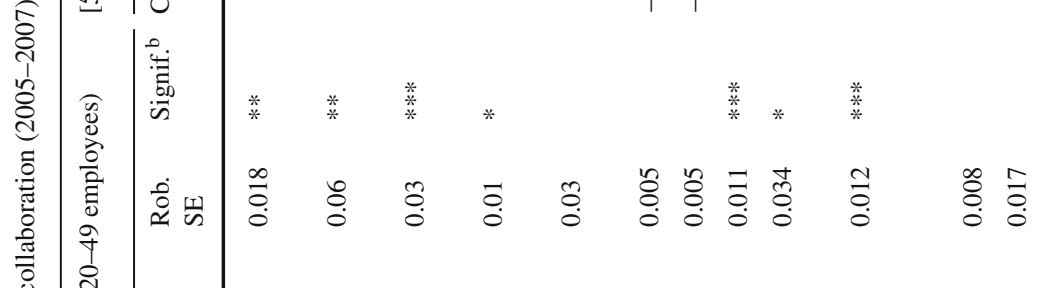

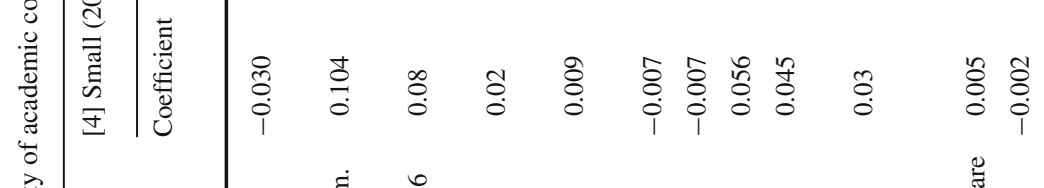

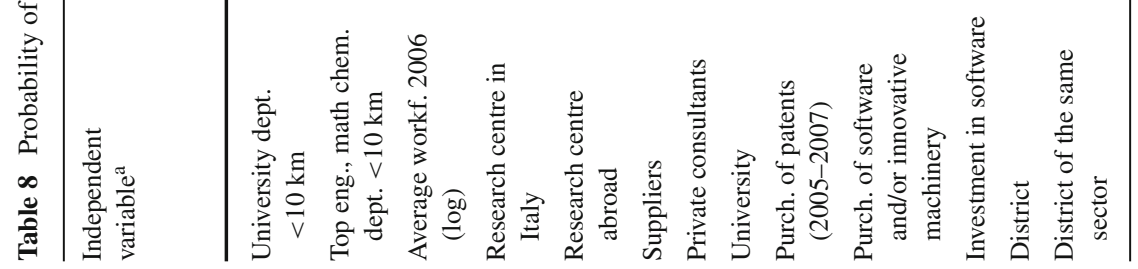




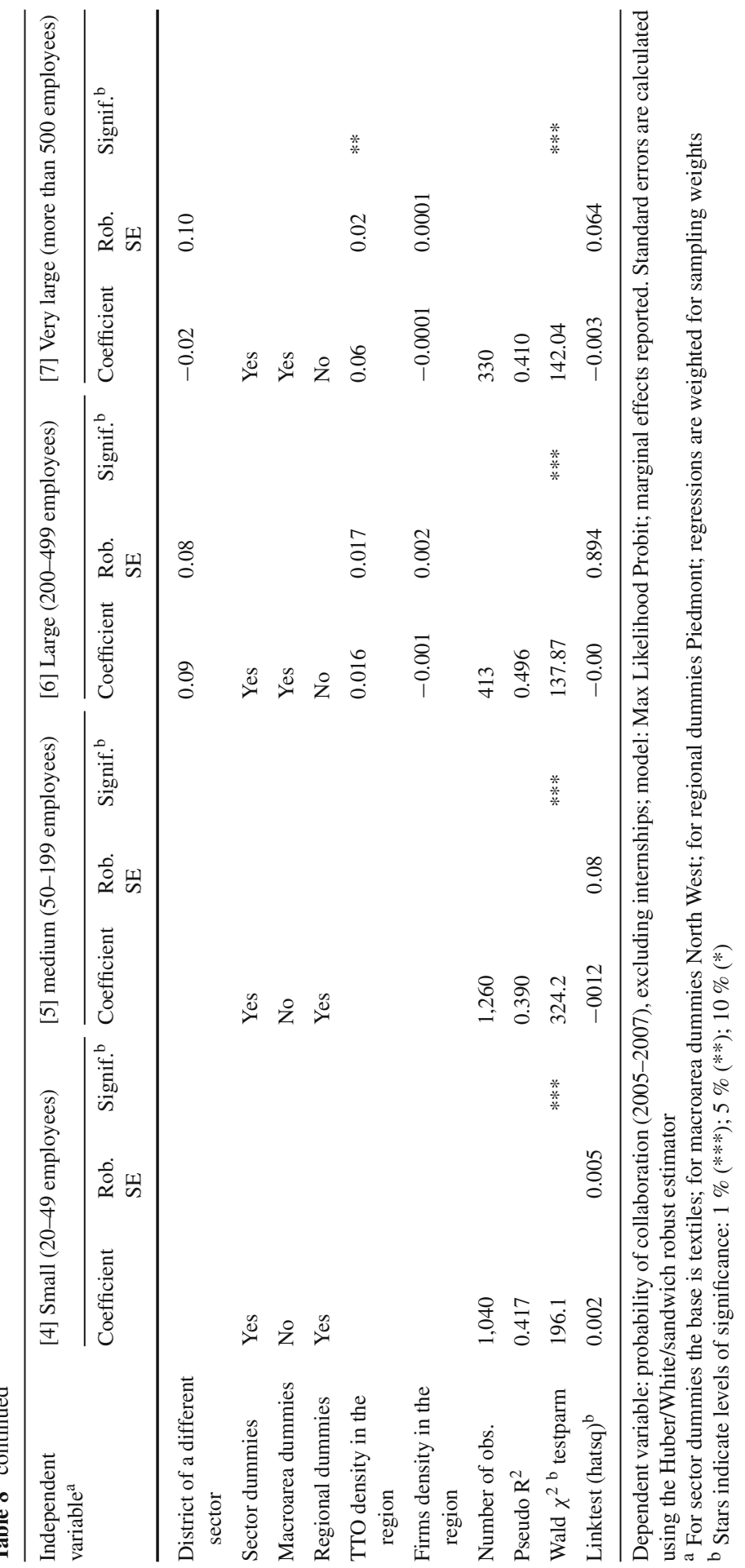


Table 9 Probability of academic collaboration (2005-2007), by sector

\begin{tabular}{|c|c|c|c|c|c|c|c|c|c|}
\hline \multirow{2}{*}{$\begin{array}{l}\text { Independent } \\
\text { variable }^{\mathrm{a}}\end{array}$} & \multicolumn{3}{|l|}{ [8] Textiles } & \multicolumn{3}{|c|}{ [9] Chemicals, rubber, plastics } & \multicolumn{3}{|c|}{ [10] Engineering } \\
\hline & Coefficient & $\begin{array}{l}\text { Rob. } \\
\text { SE }\end{array}$ & Signif. $^{b}$ & Coefficient & Rob. SE & Signif. ${ }^{b}$ & Coefficient & $\begin{array}{l}\text { Rob. } \\
\text { SE }\end{array}$ & Signif. $^{b}$ \\
\hline $\begin{array}{l}\text { Top engin./math/ } \\
\text { computer science } \\
\text { dept. }<10 \mathrm{~km}\end{array}$ & 0.12 & 0.11 & $* * *$ & & & & 0.02 & 0.04 & \\
\hline $\begin{array}{l}\text { Top engineer- } \\
\text { ing/chemistry } \\
\text { dept. }<10 \mathrm{~km}\end{array}$ & & & & -0.004 & 0.06 & & & & \\
\hline $\begin{array}{l}\text { Average workforce } \\
2006(\log )\end{array}$ & 0.000 & 0.000 & & 0.07 & 0.02 & $* * *$ & 0.07 & 0.01 & $* * *$ \\
\hline $\begin{array}{l}\text { Research centre in } \\
\text { Italy }\end{array}$ & 0.002 & 0.003 & $* *$ & 0.14 & 0.05 & $* *$ & 0.08 & 0.03 & $* *$ \\
\hline $\begin{array}{l}\text { Research centre } \\
\text { abroad }\end{array}$ & -0.00 & 0.00 & & -0.019 & 0.06 & & -0.07 & 0.03 & $*$ \\
\hline Suppliers & 0.001 & 0.001 & $* *$ & -0.03 & 0.02 & & -0.015 & 0.018 & \\
\hline Private consultants & -0.00 & 0.000 & & -0.04 & 0.02 & * & -0.007 & 0.01 & \\
\hline University & 0.003 & 0.003 & $* * *$ & 0.19 & 0.03 & $* * *$ & 0.17 & 0.02 & $* * *$ \\
\hline $\begin{array}{l}\text { Purchase of patents } \\
\quad(2005-2007)\end{array}$ & 0.031 & 0.03 & $* * *$ & 0.20 & 0.08 & $*$ & 0.02 & 0.05 & \\
\hline $\begin{array}{l}\text { Purchase of software } \\
\text { and/or innovative } \\
\text { machinery }\end{array}$ & 0.00 & 0.000 & & 0.06 & 0.04 & & 0.10 & 0.03 & $* * *$ \\
\hline $\begin{array}{l}\text { Investment in } \\
\text { software }\end{array}$ & 0.00 & 0.00 & & 0.02 & 0.02 & & 0.05 & 0.04 & \\
\hline District & 0.00 & 0.00 & & 0.02 & 0.06 & & 0.03 & 0.04 & \\
\hline Macroarea dummies & No & & & No & & & No & & \\
\hline Regional dummies & Yes & & & Yes & & & Yes & & \\
\hline Number of obs. & 241 & & & 229 & & & 904 & & \\
\hline Pseudo $\mathrm{R}^{2}$ & 0.772 & & & 0.554 & & & 0.439 & & \\
\hline Wald $\chi^{2} \mathrm{~b}$ testparm & 100.52 & & $* * *$ & 134.00 & & $* * *$ & 302.9 & & $* * *$ \\
\hline Linktest (hatsq) ${ }^{\text {b }}$ & -0.000 & 0.000 & & -0.013 & 0.004 & & -0.012 & 0.01 & \\
\hline \multirow{2}{*}{$\begin{array}{l}\text { Independent } \\
\text { variable }^{\mathrm{a}}\end{array}$} & \multicolumn{3}{|c|}{ [11] Other manufacturing } & \multicolumn{3}{|c|}{ [12] Transport and communication } & & & \\
\hline & Coefficient & $\begin{array}{l}\text { Rob. } \\
\text { SE }\end{array}$ & Signif. ${ }^{b}$ & Coefficient & $\begin{array}{l}\text { Rob. } \\
\text { SE }\end{array}$ & Signif. ${ }^{\mathrm{b}}$ & & & \\
\hline $\begin{array}{l}\text { Top } \\
\text { engineering/math/ } \\
\text { computer science } \\
\text { dept. }<10 \mathrm{~km}\end{array}$ & 0.13 & 0.09 & $*$ & 0.05 & 0.02 & $*$ & & & \\
\hline \multicolumn{10}{|l|}{$\begin{array}{l}\text { Top engineer- } \\
\text { ing/chemistry } \\
\text { dept. }<10 \mathrm{~km}\end{array}$} \\
\hline $\begin{array}{l}\text { Average workforce } \\
2006(\log )\end{array}$ & 0.04 & 0.01 & $* * *$ & 0.003 & 0.001 & & & & \\
\hline $\begin{array}{l}\text { Research centre in } \\
\text { Italy }\end{array}$ & 0.04 & 0.01 & & 0.12 & 0.09 & $* *$ & & & \\
\hline
\end{tabular}


Table 9 continued

\begin{tabular}{|c|c|c|c|c|c|c|}
\hline \multirow{2}{*}{$\begin{array}{l}\text { Independent } \\
\text { variable }^{\mathrm{a}}\end{array}$} & \multicolumn{3}{|c|}{ [11] Other manufacturing } & \multicolumn{3}{|c|}{ [12] Transport and communication } \\
\hline & Coefficient & $\begin{array}{l}\text { Rob. } \\
\text { SE }\end{array}$ & Signif. & Coefficient & Rob. SE & Signif. ${ }^{b}$ \\
\hline Research centre abroad & -0.04 & 0.03 & & -0.00 & 0.08 & \\
\hline Suppliers & 0.005 & 0.01 & & -0.005 & 0.005 & \\
\hline Private consultants & 0.018 & 0.014 & & -0.003 & 0.004 & \\
\hline University & 0.09 & 0.016 & $* * *$ & 0.03 & 0.01 & $* * *$ \\
\hline $\begin{array}{l}\text { Purchase of patents } \\
(2005-2007)\end{array}$ & 0.02 & 0.06 & & -0.002 & 0.009 & \\
\hline $\begin{array}{l}\text { Purchase of software and/or } \\
\text { innovative machinery }\end{array}$ & 0.04 & 0.03 & & 0.01 & 0.01 & $*$ \\
\hline Investment in software & -0.00 & 0.01 & & 0.001 & 0.01 & \\
\hline District & 0.01 & 0.03 & & -0.01 & 0.01 & * \\
\hline Macroarea dummies & No & & & Yes & & \\
\hline Regional dummies & Yes & & & No & & \\
\hline Number of obs. & 792 & & & 209 & & \\
\hline Pseudo $\mathrm{R}^{2}$ & 0.266 & & & 0.496 & & \\
\hline Wald $\chi^{2 \mathrm{~b}}$ testparm & 145.09 & & $* * *$ & 119.66 & & $* * *$ \\
\hline Linktest (hatsq) ${ }^{\mathrm{b}}$ & -0.004 & 0.01 & & -0.001 & 0.001 & \\
\hline
\end{tabular}

Dependent variable: probability of collaboration (2005-2007), excluding internships; model: Max Likelihood Probit; marginal effects reported. Standard errors are calculated using the Huber/White/sandwich robust estimator

${ }^{a}$ For sector dummies the base is textiles; for macroarea dummies North West; for regional dummies Piedmont; regressions are weighted for sampling weights

${ }^{\mathrm{b}}$ Stars indicate levels of significance: $1 \%(* * *) ; 5 \%(* *) ; 10 \%(*)$

In all specifications the pseudo- $\mathrm{R}^{2}$ is about 0.4 . The $\chi^{2}$ Wald $^{8}$ test rejects the hypothesis that all explanatory variables are jointly zero. The Link test ${ }^{9}$ on the specification of the dependent variable rejects the hypothesis of misspecification.

The proximity of the firm to top-rated departments in important fields increases the probability of academic collaboration: its coefficient is significantly different from zero always over the $5 \%$ level of confidence. It doubles in value and becomes significant at the $1 \%$ level when regional dummies are inserted, controlling for regional fixed effects. It is interesting to note that proximity to a university not characterized by high quality research in important subjects does not exert any significant impact on the probability of collaboration. What matters therefore is not the widespread supply of research but the supply of important top quality research.

\footnotetext{
8 The $\chi^{2}$ Wald test is an asymptotic test on the null hypothesis that all the coefficients of explanatory variables are jointly equal to zero.

9 The Link test (Pregibon 1979, 1980) is a test on the specification of the dependent variable, based on the detection of a link error; the model is re-estimated, including estimates of $y$ and its square among regressors. It is plausible that if the latter is significant, then there is a specification error: the null hypothesis is that this coefficient is not significant.
} 
The probability of collaboration is positively correlated with firm size, with investments in ICT and with the presence of an intra-mural research centre (while the existence of a research centre abroad has no effect). The purchase of software or innovative equipment, the purchase of patents, and the importance of university as a source of innovation, all show positive and significant coefficients; the importance of private consultants does not show any important effect; the reliance on suppliers as a source of innovation decreases the probability of research collaboration.

Results indicate that the presence of different sources of innovation, both intramural and external, increases the probability of research collaboration between firms and universities. The hypothesis that public research can simply replace the (lack of) research (not) conducted by firms is rejected. ${ }^{10}$ The importance of firm size supports the view that the firm must possess a set of specific skills to be able to capture, understand and commercially exploit the results of academic research (the concept of absorptive capacity, Cohen and Levinthal 1990, or of cognitive proximity, as in Boschma 2005). Hence, policies aiming at encouraging firms' dimensional growth can spur innovation through the channel of research collaboration, in addition to the commonly accepted argument claiming that larger firms can more easily sustain the fixed costs of R\&D (Rossi 2006; Bugamelli et al. 2012).

As explained above, if the firm considers the relationship with suppliers an important source of innovation, the probability of academic collaboration decreases. This result seems to suggest that networks of firms can represent a substitute for agreements with universities. The coefficient on the district variable, though, is never significantly different from zero. This could be due to the structure of the sample, limited to firms with more than 20 employees, less well oriented to take advantage of district networks. $^{11}$

We then portioned the sample by size (Table 8): small firms (20-49 employees), medium ones (50-199 employees), large ones (between 200 and 499 employees) and very large ones (over 500 employees). We also included the number of Technology Transfer Offices (TTOs) in the region as an explanatory variable and we normalized it on the number of firms with over 20 employees. The hypothesis that we wanted to test is whether the presence of commercially-oriented universities in the same area as the firm increases the probability of collaboration. ${ }^{12}$

For small firms the results are quite similar to those for the entire sample: the effect of a firm's proximity to top-rated departments is highly significant and larger in magnitude than in the pooled regression. This seems to confirm the hypothesis that distance represents a greater obstacle to collaboration for smaller firms, which are less

\footnotetext{
10 For a literature review on this topic see also Rodriguez-Pose and Refolo (2000).

11 We also checked for the effect of science parks. This coefficient is not significant either. Results available upon request.

12 For the whole sample and in the sectoral regressions this variable is never significant; it was dropped in favour of regional dummies (for a full description see Appendix).
} 
able to bear its costs. ${ }^{13}$ Investments in software and relationships with suppliers do not exert any significant effect. ${ }^{14}$

Also for medium-sized firms the effect of proximity to top quality departments in important fields is significant; coefficients for external sources of innovation increase in significance and magnitude. The presence of a generic university does not show any effect.

For large and very large firms only, distance from top quality departments does not seem to have any significant effect on the probability of collaboration with universities. ${ }^{15}$ For large enterprises the cost of distance is probably not a decisive factor in the choice of establishing relations with one particular university. Moreover, for very large firms the commercial orientation of universities is a key feature in determining the probability of collaboration. The presence of a research centre abroad increases the probability of collaboration; the purchase of patents does not show any significant effect and belonging to a district of the same sector negatively affects the probability of agreements. Larger firms seem to choose universities that are better able to sell the results of their research and appear able to exploit their size to capture district synergies in the most fruitful way.

Table 9 reports the results of sector regressions for textiles, chemicals, engineering, other manufacturing, transport and communications; for each sector, only subjects considered as important by the specific industry were taken into account in defining variables. ${ }^{16}$ Proximity to important departments of excellence is significant and important for the textile, other manufacturing and transportation industries. It is not significant for chemicals and engineering.

\subsection{Robustness Checks}

The definition of the variable measuring the firm's distance from important top-rated departments is the first area in which we performed robustness checks. By definition dummy variables have a more limited explanatory content than continuous ones. A strategy based on checking for a complete range of different definitions for the dummy, though, turns out to be a difficult task, given the arbitrariness in defining the threshold in kilometres within which the university should be located so that the variable assumes a value of 1 . Some controls of this type were made but they do not alter the

\footnotetext{
13 Piergiovanni et al. (1997), using data on patents for Italian provinces, find that local spillovers from academic research are important in generating innovation for small firms but not for large ones (where internal sources prevail).

14 For smaller firms, proximity to a generic university decreases the probability of collaboration. This result is in line with the findings in Laursen et al. (2008), who highlight that what matters is the distance-quality ratio and that being in the proximity of a low quality university can harm academic collaboration.

15 All comments on the difference of the coefficients across subsamples were checked by means of $t$-tests on the null hypothesis that coefficients are equal. The null is always rejected at the $5 \%$ level of confidence (results available upon request).

16 We have not reported results for the Energy sector, given the small number of observations (72).
} 
conclusions and are not, therefore, shown in the tables. ${ }^{17}$ Table 10 shows the results of regressions on the entire sample where the explanatory variable is either the average or the minimum distance from important top-rated departments (the second case models the idea that the highest importance is placed on the quality of the nearest department, as the number of collaboration opportunities is limited). The results were confirmed: a greater distance from important top-quality departments has a significantly negative impact on the probability of collaboration.

The inclusion of other characteristics of a firm (such as firm's age, ${ }^{18}$ the share of exported sales or the log of workforce in 2004) does not change the regression results in any case. ${ }^{19}$ The international openness of the firm does not exert any significant effect on the probability of academic collaboration. The use of more precise sectoral dummies $^{20}$ shows that, within the chemical industry, pharmaceutical companies and manufacturers of plastics are more willing to have research collaboration; oil companies appear to be less willing to do so.

As shown in Abramovsky and Simpson (2008), the geographical proximity measure may give rise to a (probable) endogeneity problem, because more innovative companies tend to locate near scientific research centres of excellence. ${ }^{21}$ These results must be considered as evidence of "co-movement" rather than of causality in a strict sense. Although a complete analysis of the issue of endogeneity lies beyond the scope of this work, in Table 11 we report estimates obtained using an instrumental variables probit approach, in order to address the problem more systematically.

The characteristics that an instrument must have are: being important i.e. correlated with the explanatory variable to be instrumented, and being exogenous i.e. not affected by the same problem as the original regressor. The distance of the firm from toprated research centres in "Ancient History, Philological-Literary and Historical Arts" (as defined in the VTR, MIUR 2006) seems to meet these requirements. Top-rated humanities departments and top-rated scientific departments tend to locate together: the correlation between the average distance of firms from top-rated scientific departments and from top-rated humanities departments is 0.80 . First-step estimates confirm that the instrument is relevant (Table 12). Nevertheless, the location of top humanities

\footnotetext{
17 Results are robust to different definitions of the variable. For example, in substitution for the described dummy, we inserted a regressor that counts the number of high quality, important scientific departments in the $10 \mathrm{~km}$ range; in another exercise the dummy has been replaced by a discrete variable taking the value of zero if there is no qualified research within $10 \mathrm{~km}, 1$ if there is one department, 2 if there are two departments dealing with different fields (to assess the effect of more diversified scientific research). Finally we checked the robustness of our results inserting a dummy variable taking the value of 1 if there is at least a high quality, important scientific department within the local labour system where the firm is located: this alternative definition is meant to capture a more functional concept of distance between firms and universities. The results do not change.

18 We have also added a quadratic term to capture possible non linear effects. No significant age effects emerge from the analysis. Results available upon request.

19 Results available upon request.

20 Results available upon request.

21 See also Rodriguez-Pose and Refolo (2003), who show that the development of clusters of small firms in Italy is influenced by the presence of universities in the same area and the quality of their research.
} 
Table 10 Probability of academic collaboration (2005-2007), robustness checks

\begin{tabular}{|c|c|c|c|c|c|c|}
\hline \multirow[t]{2}{*}{ Independent variable $\mathrm{e}^{\mathrm{a}}$} & \multicolumn{3}{|c|}{ [1] Average distance } & \multicolumn{3}{|c|}{ [2] Minimum distance } \\
\hline & Coefficient & Rob. SE & Signif. $^{b}$ & Coefficient & Rob. SE & Signif. ${ }^{b}$ \\
\hline University dept. $<10 \mathrm{~km}$ & -0.008 & 0.01 & & -0.01 & 0.01 & \\
\hline Minimum distance from top dept. & & & & -0.0004 & 0.000 & $*$ \\
\hline Average distance from top dept. & -0.0005 & 0.000 & $* * *$ & & & \\
\hline Average workforce 2006 (log) & 0.03 & 0.004 & $* * *$ & 0.03 & 0.004 & $* * *$ \\
\hline Research centre in Italy & 0.05 & 0.01 & $* * *$ & 0.05 & 0.01 & $* * *$ \\
\hline Research centre abroad & 0.03 & 0.03 & & 0.03 & 0.03 & \\
\hline Suppliers & -0.01 & 0.006 & $*$ & -0.01 & 0.006 & $*$ \\
\hline Private consultants & -0.008 & 0.005 & & -0.008 & 0.005 & \\
\hline University & 0.09 & 0.010 & $* * *$ & 0.09 & 0.010 & $* * *$ \\
\hline Purchase of patents (2005-2007) & 0.06 & 0.03 & $* * *$ & 0.05 & 0.02 & $* * *$ \\
\hline $\begin{array}{l}\text { Purchase of software and/or } \\
\text { innovative machinery }\end{array}$ & 0.04 & 0.01 & $* * *$ & 0.04 & 0.01 & $* * *$ \\
\hline Investment in software & 0.003 & 0.00 & $* * *$ & 0.004 & 0.00 & $* * *$ \\
\hline District & 0.008 & 0.17 & & 0.01 & 0.01 & \\
\hline Sector dummies & Yes & & & Yes & & \\
\hline Macroarea dummies & No & & & No & & \\
\hline Regional dummies & Yes & & & Yes & & \\
\hline Number of obs. & 3,102 & & & 3,102 & & \\
\hline Pseudo $\mathrm{R}^{2}$ & 0.407 & & & 0.405 & & \\
\hline Wald $\chi^{2 \mathrm{~b}}$ testparm & 645.27 & & $* * *$ & 648.48 & & $* * *$ \\
\hline Linktest (hatsq) ${ }^{\mathrm{b}}$ & -0.004 & 0.004 & & -0.004 & 0.004 & \\
\hline
\end{tabular}

Dependent variable: probability of collaboration (2005-2007), excluding internships; model: Max Likelihood Probit; marginal effects reported. Standard errors are calculated using the Huber/White/sandwich robust estimator

a For sector dummies the base is textiles; for macroarea dummies North West; for regional dummies Piedmont; regressions are weighted for sampling weights

b Stars indicate levels of significance: $1 \%(* * *) ; 5 \%(* *) ; 10 \%(*)$

departments does not affect the location decision of firms, as it does not present any ex ante advantages for them.

Table 11 reports the results of the regression in which the average distance from top-rated scientific research centres is instrumented by the distance from top-rated humanities departments. The Wald test of exogeneity indicates that there is not enough information to reject the null hypothesis of the exogeneity of the original regressor. ${ }^{22}$ Therefore the probit estimation produces consistent and efficient coefficients. In any case, the instrumental variable estimation, although less precise, confirms that the location of top-rated scientific departments positively influences the probability of collaboration.

\footnotetext{
22 If the Wald statistics are not significant (as in our case), there is not enough information in the sample to reject the null hypothesis of non endogeneity. See Hakkala et al. (2008).
} 
Table 11 Probability of academic collaboration (2005-2007), endogeneity checks

\begin{tabular}{|c|c|c|c|}
\hline \multirow[t]{2}{*}{ Independent variable ${ }^{\mathrm{a}}$} & \multicolumn{3}{|c|}{ [1] Instrumental variable } \\
\hline & Coefficient & Rob. SE & Signif. ${ }^{b}$ \\
\hline University dept. $<10 \mathrm{~km}$ & -0.062 & 0.134 & \\
\hline $\begin{array}{l}\text { Average distance from top university (=average distance } \\
\text { from top humanities department) }\end{array}$ & -0.005 & 0.002 & $* *$ \\
\hline Average workforce $2006(\log )$ & 0.299 & 0.041 & $* * *$ \\
\hline Research centre in Italy & 0.377 & 0.110 & $* * *$ \\
\hline Research centre abroad & 0.231 & 0.222 & \\
\hline Suppliers & -0.095 & 0.051 & $*$ \\
\hline Private consultants & -0.069 & 0.047 & \\
\hline University & 0.787 & 0.055 & $* * *$ \\
\hline Purchase of patents (2005-2007) & 0.400 & 0.139 & $* * *$ \\
\hline Purchase of software and/or innovative machinery & 0.365 & 0.111 & $* * *$ \\
\hline Investment in software & 0.031 & 0.010 & $* * *$ \\
\hline District & 0.071 & 0.140 & \\
\hline Sector dummies & Yes & & \\
\hline Macroarea dummies & No & & \\
\hline regional dummies & Yes & & \\
\hline Constant & -1.96 & 0.802 & $* *$ \\
\hline Number of obs. & 3,102 & & \\
\hline Wald $\chi^{2 \mathrm{~b}}$ testparm & 649.94 & & $* * *$ \\
\hline Wald test of exogeneity $\chi^{2 \mathrm{a}}=0.18$ Prob $>\chi^{2}=0.67$ & & & \\
\hline
\end{tabular}

Dependent variable: probability of collaboration (2005-2007), excluding internships; model: Instrumental variable Probit; marginal effects reported. Standard errors are calculated using the Huber/White/sandwich robust estimator

${ }^{\text {a }}$ For sector dummies the base is textiles; for macroarea dummies North West; for regional dummies Piedmont; regressions are weighted for sampling weights

b Stars indicate levels of significance: $1 \%(* * *) ; 5 \%(* *) ; 10 \%(*)$

\section{Conclusions}

In this paper we examine the determinants of research collaboration between firms and universities or public research centres in Italy in 2005-2007, using the results of the 15th wave of the Bank of Italy Business Outlook Survey based on a sample of about 4,000 industrial and non-financial service firms with at least 20 employees. We focus on various research questions: how much is geographic proximity important for collaboration? What is the role of the quality of academic research in important subjects? What is the importance of informal interactions between public and private researchers? What are the characteristics of a firm that can facilitate such relationships? Do active commercial policies by universities help foster agreements?

We estimate a multivariate probit model for the probability of firm/university collaboration. In order to evaluate research quality we merged the ranking provided by 
Table 12 Probability of academic collaboration (2005-2007), endogeneity checks, first-step estimation

\begin{tabular}{|c|c|c|c|}
\hline \multirow[t]{2}{*}{ Independent variable ${ }^{\mathrm{a}}$} & \multicolumn{3}{|c|}{ [1] Instrumental variable } \\
\hline & Coefficient & Rob. SE & Signif. ${ }^{b}$ \\
\hline University dept. $<10 \mathrm{~km}$ & 1.7 & 0.78 & $*$ \\
\hline Average distance from top humanities departments & 0.76 & 0.06 & $* * *$ \\
\hline Average workforce $2006(\log )$ & 0.09 & 0.24 & \\
\hline Research centre in Italy & -0.19 & 0.58 & \\
\hline Research centre abroad & 1.9 & 0.89 & $* *$ \\
\hline Suppliers & 0.24 & 0.23 & \\
\hline Private consultants & -0.24 & 0.22 & \\
\hline University & -0.13 & 0.31 & \\
\hline Purchase of patents (2005-2007) & 2.11 & 0.89 & $* *$ \\
\hline Purchase of software and/or innovative machinery & -0.99 & 0.53 & $*$ \\
\hline Investment in software & -0.06 & 0.03 & \\
\hline District & -0.21 & 0.64 & \\
\hline Sector dummies & Yes & & \\
\hline Macroarea dummies & No & & \\
\hline regional dummies & Yes & & \\
\hline Constant & 10.2 & 2.3 & $* * *$ \\
\hline Number of obs. & 3102 & & \\
\hline$R^{2}$ & 0.09 & & \\
\hline $\mathrm{F}(39,3120)$ & 6.21 & & $* * *$ \\
\hline
\end{tabular}

Dependent variable: average distance from top-rated important departments; model: OLS. Standard errors are calculated using a robust estimator

${ }^{a}$ For sector dummies the base is textiles; for macroarea dummies North West; for regional dummies Piedmont; regressions are weighted for sampling weights

b Stars indicate levels of significance: $1 \%(* * *) ; 5 \%(* *) ; 10 \%(*)$

the Triennial Evaluation Research Project (VTR), conducted by the Italian Ministry of Education and Research, with the Carnegie Mellon Survey (CMS), which quantifies the importance of ten research fields for various manufacturing sectors in the USA. Through the CMS we paired each firm with the most important subjects for its own sector, and through the VTR we singled out the best departments for each subject in Italy, checking for firm/department geographic distance. Other determinants include firms' characteristics, such as size and openness to different sources of innovation, and the commercial orientation of universities.

Results indicate that the likelihood of being involved in research collaboration is positively correlated to the firm's proximity to important top quality research centres. Physical proximity to any generic (low) quality research department does not influence the probability of research agreements with universities. Other results indicate that the presence of different innovation sources increases this probability; so does firm size. Proximity is more important for small and medium-sized firms, while large ones collaborate with universities that are better able to sell the results of their research, 
regardless of their location since distance represents a cost that large firms are better able to bear.

Robustness checks have been conducted to address the issue of endogeneity related to the location choice of firms (innovative firms tend to concentrate near top-rated universities), using a firm's proximity to top-rated departments in humanities. Other checks include a different specification for the distance variable and the use of additional controls for firms or geographic distance. The results are robust to the different specifications.

These results suggest that geographic proximity favours research agreements; the literature considers informal relations between public and private researchers as one of the main drivers of the occurrence of collaboration. These contacts are made easier if the subjects share a common ground of knowledge, thus physical proximity may therefore be a proxy for cognitive and social proximity.

Similarly, the importance of size in influencing the probability of collaboration supports the view that the firm must possess "absorptive capacity" in order to be able to capture, understand and commercially exploit the results of academic research. This is a set of specific skills more easily found in larger firms. Moreover, large firms are better able to create synergies among different sources of innovation; the hypothesis that public research can completely compensate for the lack of internal research is rejected. An implication of this result is that policies aiming at encouraging firms to grow in size can spur innovation through the channel of research collaboration, in addition to the commonly accepted argument claiming that larger firms can more easily sustain the fixed costs of R\&D and of investment in knowledge.

Lastly, the importance of quality has another implication for policy. For the average firm, and especially for small ones, what is crucial for academic collaboration is proximity to a high quality university in important fields (broadly speaking, in technical subjects). Therefore, an increase in the diffusion of universities can encourage collaboration only if it is accompanied by an increase in the quality of the research produced therein. In Italy, following Ministerial Decree 509/1999 which introduced 3 -year degree programmes, there has been a marked proliferation in the number of universities: in 2008 there were 95 of them (including web universities, and excluding the many satellite locations), almost twice as many than in the early 1980s. Such a widespread supply may be ineffective if it does not go hand in hand with quality in research. An excessive dispersion may prevent universities from having a sufficient concentration of scholars to produce important research, transforming these institutions into centres dedicated primarily to teaching.

\section{Statistical Tables}

See Tables 2, 3, 4, 5, 6, 7, 8, 9, 10, 11 and 12 .

\section{Appendix: Balance Sheet Indicators for Italian Universities}

The financial statements of Italian universities are compiled according to harmonized criteria and made available by the Ministry for Education, Universities and Research 


\section{Human resources/Ffo}

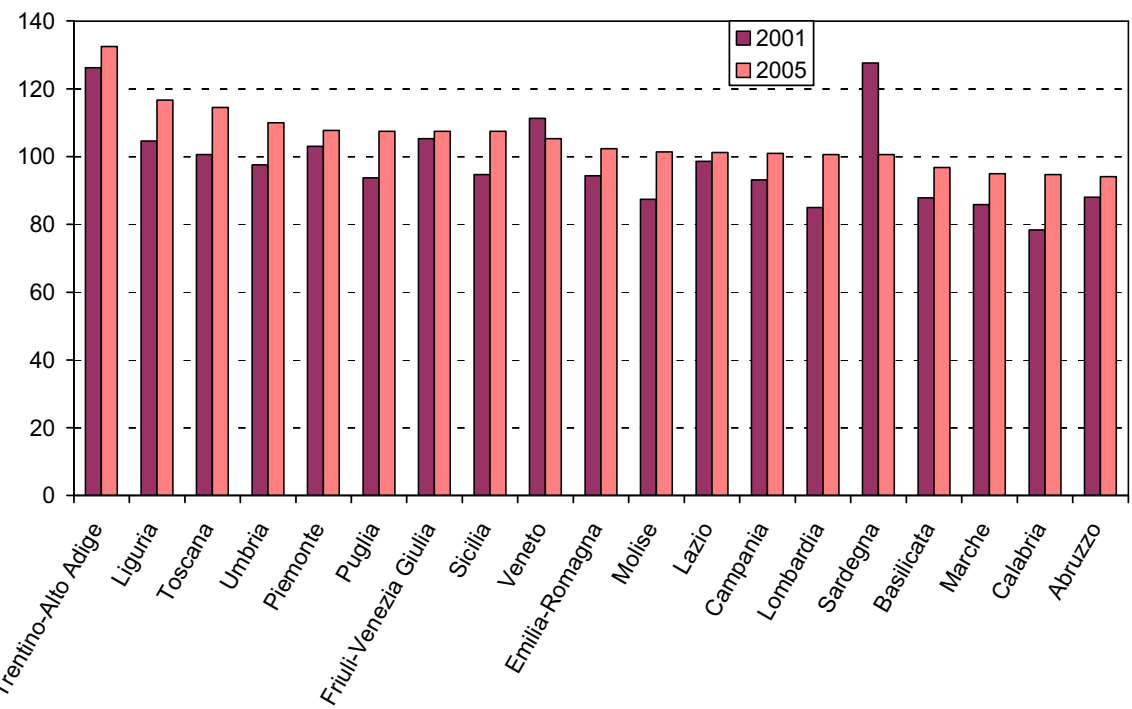

Fig. 4 Balance sheet indicators of regional university systems in Italy: (1) (percent). Source Ministry of Education, University and Research. (1) Balance sheet items used for indicators are at current euro prices. Human resources are total staff costs. Third parties include own revenues from contracts with companies and from sale of goods and services; they exclude other own revenues. The denominator is the Ordinary Financing Fund (Ffo)

(MIUR). Revenue items include transfers from the Government, local authorities, the European Union or other bodies, student fees, income from the sale of goods and services, rent and interest. Expenditure items include staff and current expenses, interventions for students, purchases of durables and financial charges.

State universities are funded by the central government through the Ordinary Financing Fund (Ffo). The Fund, established in 1993, is used to finance universities mainly on the basis of past spending corrected for research output and teaching load (using the model devised by the National Agency for University Evaluation, ANVUR). ${ }^{23}$ In 2007-2009, on average, the fund reached about $€ 7$ billion; between 2011 and 2013 it will decrease by more than $5 \%$. The fund is almost completely used to cover staff costs. ${ }^{24}$ The ratio of total expenditure for human resources and the $\mathrm{Ffo}^{25}$ can be interpreted as the inverse of universities' productivity, which is decreasing. The indicator has modest regional variability (Fig. 4); larger and more developed regions are not necessarily the most efficient ones.

\footnotetext{
23 Research is evaluated looking at the number of researchers that successfully applied for Italian or European funds and at the quality of the findings after peer review. Teaching quality is assessed on the basis of the number of students, the share of employed graduates, the number of full professors and the presence of an internal quality monitoring system.

24 According to the 1998 Budget Law, universities can use at most $90 \%$ of the Ffo to cover staff costs.

25 Our indicator is different from the one used for legal purposes, as it includes all staff costs.
} 


\section{Third parties/Ffo}

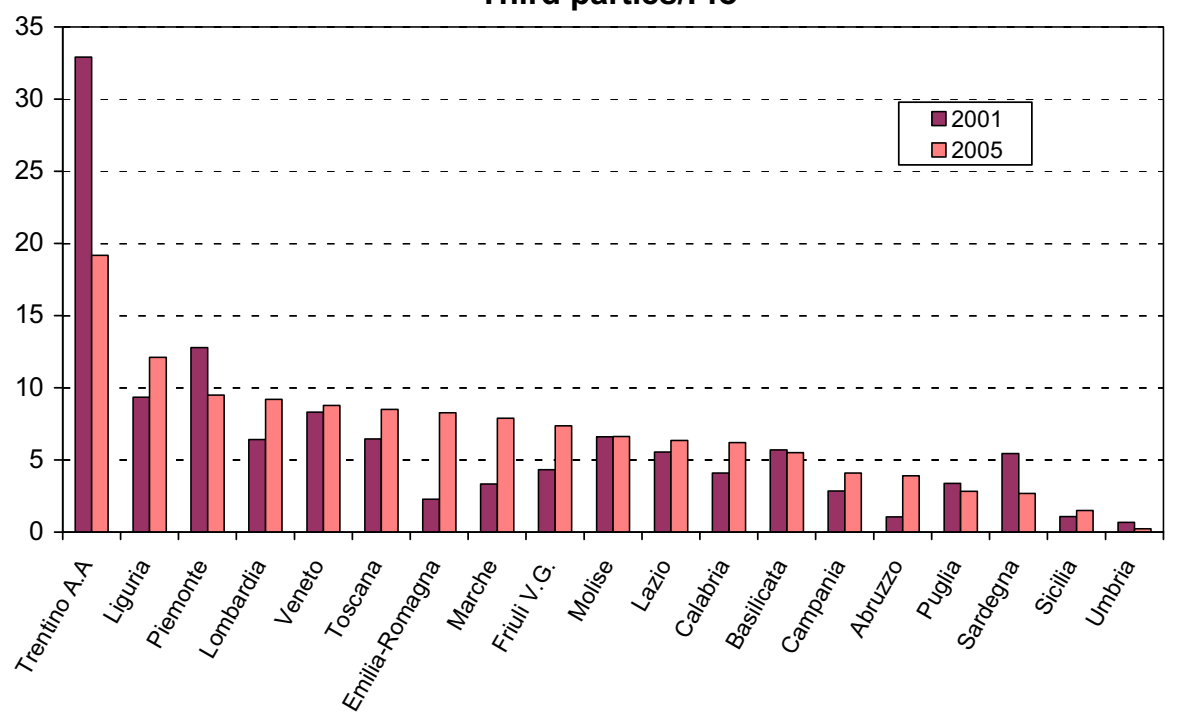

Fig. 5 Balance sheet indicators of regional university systems in Italy: (1) (percent). Source Ministry of Education, University and Research. (1) Balance sheet items used for indicators are at current euro prices. Human resources are total staff costs. Third parties include own revenues from contracts with companies and from sale of goods and services; they exclude other own revenues. The denominator is the Ordinary Financing Fund (Ffo)

With almost all of the state funds employed to cover staff costs, the incentive for universities to seek private funding has increased. An indicator of universities' entrepreneurial spirit is the incidence of revenues from contracts with private companies (hereinafter, "Third parties") in the Ffo. ${ }^{26}$ Between 2001 and 2005, the average Third parties/Ffo indicator increased from 5.0 to $5.8 \%$; the growth in median values was stronger (from 3.9 to $5.2 \%$ ). ${ }^{27}$ The variability among universities translates into marked differences among the various regional systems (Fig. 5): in 2005 Trentino-Alto Adige and the North West regions registered a share of private funding in the Ffo of around or over $10 \%$, while the South and Islands reached a value close to half the Italian average. The most dynamic universities also adopted internal policies based on incentives to professors, mainly in the form of profit sharing, increases in research

\footnotetext{
${ }^{26}$ An alternative indicator is the incidence of private funding in expenditure for human resources. The two measures are highly correlated (0.98).

27 This indicator differs from other measures suggested by previous studies: Colombo et al. (2010) use the share of privately funded research on total research funds, on average $2.7 \%$ in 2003-2004; Bonaccorsi and Granelli (2005) use the share of funds provided by industry (around 3-5\% in the period 1995-1999); OECD (2006) estimates that the share of funds from firms and foundations in total private funds amounted to $9 \%$ in 2003.
} 
funds or career advancement (Netval 2006 ${ }^{28}$ ): between 2001 and 2005, the incidence of the Third parties account in the Ffo increased significantly in many regions.

As an additional tool to attract resources from firms, Italian universities intensified their policies for the commercialization of research results. The creation of dedicated structures was rather new for Italy: before 1985 there were none (Netval 2008). The first TTO (Technology Transfer Office) was established in 1997, 20 years later than in most advanced European countries. In 2007, 42 out of the 63 universities analysed had a TTO, ${ }^{29}$ actively engaged in the commercial exploitation of intellectual property and in the management of contracts with firms.

Spin-offs are not a widespread phenomenon in Italy either. Academic spin-offs are defined as entrepreneurial initiatives of an academic nature often linked to the exploitation of a patented invention. ${ }^{30}$ Up to the early 1980 s these constituted sporadic episodes, looked at with indifference by universities; they became more common in the 2000s, partly as a result of institutional changes. ${ }^{31}$

According to the RITA database (2005), developed by the Department of Management Economics and Industrial Engineering at the Politecnico di Milano on nearly 2,000 new high-tech companies, there were 123 academic start-ups in Italy (using the narrow definition excluding student enterprises), nearly half of which were established after 2000. According to the survey developed by the Scuola Superiore Sant'Anna of Pisa and including student entrepreneurs (Piccaluga and Balderi 2006), there were 710 spin-offs 710 (Netval 2008). In either case the number is modest, much more so than in other European countries, Canada or the United States (Finlombarda 2006).

\section{References}

Abramovsky L, Harrison R, Simpson H (2007) University research and the location of business R\&D. Econ J 117:C114-C141

Abramovsky L, Simpson H (2008) Geographic proximity and firm-university innovation linkages: evidence from Great Britain. The Centre for Market and Public Organisation 08/200, Department of Economics, University of Bristol, UK

\footnotetext{
28 More than $85 \%$ of the 37 universities analysed in Netval (2006) adopted profit sharing mechanisms for professors; about $10 \%$ recognized technology transfer as a criterion to distribute research funds; $9 \%$ of the sample used it for career advancement purposes.

29 See also Mori (2008). Netval (2008) finds 54 TTOs out of 65 interviewed universities; this number, however, includes private and web-based universities and therefore is not comparable to ours.

30 Spin-offs from public research-sometimes called academic start-ups-are defined as a newly established company operating in high-tech industries, whose founding group includes professors, researchers and students at public research institutions, who may leave or stay bound to the institution of origin to start the company (RITA 2005). This definition, more common in the literature, explicitly excludes companies founded by students. Netval (2008), instead, uses the broad definition proposed in Piccaluga and Balderi (2006) which includes students among founders, provided they have carried out many years of research on a specific issue, usually at the centre of the firm's activity.

31 Parliament regulated the subject in Law 297/1999 and the subsequent Ministerial Decree 593/2000, which ordered the whole system of incentives for research and innovation by providing, among other things, a free grant for high-tech spin-offs. Law 88/2000 established a scheme of public co-financing for start-ups, albeit with modest results (Finlombarda 2006). Law 383/2001 recognized the individual ownership of any patents developed within the university: although criticized by most of the Italian universities, it has helped to foster a culture of commercially-oriented research.
} 
Arrow K (1962) Economic welfare and the allocation of resources for invention. In: The Rate and direction of inventing activity: economic and social factors. NBER. Princeton University Press, Princeton

Bade F, Nerlinger EA (2000) The spatial distribution of new technology-based firms. Pap Reg Sci 79:155176

Banca d'Italia (2007) Business outlook survey of industrial and service firms. Supplements to the Statistical Bulletin, Sample Surveys, vol XVII, no 65, Nov, Rome. Available online at http://www.bancaditalia. it/statistiche/indcamp/sondaggio/suppl_boll_stat/sb65_07/en_supp_65_2007.pdf

Bercovitz J, Feldman MP (2006) Entrepreneurial universities and technology transfer: a conceptual framework for understanding knowledge-based economic development. J Technol Transf 31(1):175-188

Bonaccorsi A, Granelli A (2005) L'intelligenza si industria. Creatività e innovazione per un nuovo modello di sviluppo. Il Mulino AREL, Bologna

Boschma RA (2005) Proximity and innovation: a critical assessment. Reg Stud 39:61-74

Breno E, Fava GA, Guardabasso V, Stefanelli M (2002) La ricerca scientifica nella università italiane. Una prima analisi delle citazioni della banca dati ISI, CRUI, Roma

Breznitz SM, Feldman MP (2012) The engaged university. J Technol Transf 37(2):139-157

Bugamelli M, Cannari L, Lotti F, Magri S (2012) Il gap innovativo del sistema produttivo italiano: radici e possibili rimedi. Questioni di economia e Finanza (Occasional Papers), no 121, April, Banca d'Italia, Rome

Buganza T, Bandoni P, Verganti R (2007) Le relazioni tra impresa e università nel paradigma dell'open innovation. Impresa and Stato, terza serie, anno 20, no 78, Franco Angeli, Milano, pp 9-16

Cohen WM, Levinthal DA (1990) Absorptive capacity: a new perspective on learning and innovation. Adm Sci Q 35:128-152

Cohen W, Nelson R, Walsh J (2002) Links and impacts: the influence of public research on industrial R\&D. Manag Sci 48(1):1-23

Colombo MG, D'Adda D, Piva E (2010) The contribution of university research to the growth of academic start-ups: an empirical analysis. J Technol Transf 35(1):113-140

CRUI (2007) Approfondimenti, n. 3, luglio

Di Gregorio D, Shane S (2003) Why do some universities generate more start-ups than others? Res Policy 32:209-227

Feller I, Feldman MP (2010) The commercialization of academic patents: black boxes, pipelines, and Rubik's cubes. J Technol Transf 35(6):597-616

Finlombarda (2006) Quinto quaderno sugli strumenti di finanza innovativa a supporto degli spin-off accademici, Milano

Gertler MS (2005) Tacit knowledge, path dependency and local trajectories of growth. In: Fuchs, Shapira (eds) Rethinking regional innovation and change. Springer, Berlin

Greene WH (1993) Econometric analysis. McMillan, New York, p 637

Hakkala K, Norback P, Svaleryd H (2008) Asymmetric effects of corruption on FDI: evidence from Swedish multinational firms. Rev Econ Stat 90(4):627-642

Istat, La Ricerca e sviluppo in Italia, various years, Roma

Jaffe AB (1989) Real effects of academic research. Am Econ Rev 79:957-970

Katz JS, Martin BR (1997) What is research collaboration? Res Policy 26:1-18

Kleinknecht A (1987) Measuring R\&D in small firms: how much are we missing? J Ind Econ 86:253-256

Laursen K, Reichstein T, Salter A (2008) Exploring the effects of geographical proximity on industry university collaboration in the UK. Res Policy 33:1201-1215

Lundvall B-A (ed) (1992) National systems of innovation. Pinter, London

Mansfield E, Lee J (1996) The Modern University: contributor to industrial innovation and recipient of industrial R\&D support. Res Policy 25:1047-58

Ministero dell'Istruzione, dell'Università e della Ricerca, Comitato di Indirizzo per la Valutazione della Ricerca (2006) Risultati della Valutazione dei Panel di Area, Roma 26 Gennaio 2006

Mori A (2008) Innovazione e trasferimento tecnologico: il rapporto tra imprese e università. In: Banca d'Italia, Leconomia delle regioni italiane nell'anno 2007, Economie regionali no 1, Roma, pp 53-55

Nelson R (1986) Institutions supporting technical advance in industry. Am Econ Rev 76:186-189

Netval (2006) La valorizzazione della ricerca nelle università italiane. Quarto rapporto annuale. http://www. netval.it

Netval (2008) Brevetti e imprese per il sistema Paese: il contributo dell'università. Sesto rapporto Netval sulla valorizzazione della ricerca nelle università italiane. http://www.netval.it

OECD (2006) Education at a glance. OECD, Paris 
Piccaluga A, Balderi C (2006) Consistenza ed evoluzione delle imprese Spin-off della ricerca pubblica in Italia, IN-SAT Lab, Scuola Superiore di Sant'Anna, Pisa

Pietrabissa R, Conti G (2005) Strategia per un rapporto responsabile fra ricerca pubblica e industria. L'industria. Il Mulino, Bologna, pp 419-444

Piergiovanni R, Santarelli E, Vivarelli M (1997) From which source do small firms derive their innovative inputs? Some evidence from Italian industry. Rev Ind Organ 12:243-258

Polanyi M (1969) Knowing and being. University of Chicago Press, Chicago

Pregibon D (1979) Goodness of link tests for generalized linear models. PhD Dissertation, University of Toronto, Mimeo

Pregibon D (1980) Data analytic methods for generalized linear models. Appl Stat 29:15-24

Rasiah R, Govindaraju G (2009) University industry collaboration in the automotive, biotechnology and electronic firms in Malaysia. University of Malaysia WP, Kuala Lumpur

RITA (2005) II Rapporto. Dipartimento di Ingegneria Gestionale, Politecnico di Milano

Rodriguez-Pose A, Refolo MC (2000) The link between clusters of SMEs and public and University Research in Italy. In: European Regional Science Association, 40th Congress, Barcelona

Rodriguez-Pose A, Refolo MC (2003) The link between local production systems and public and university research in Italy. Environ Plan A 35:1477-1492

Rosa J, Mohnen P (2008) Knowledge transfers between canadian business enterprises and universities: does distance matter? UNU-MERIT Working Paper No 2008-017

Rossi S (2006) La regina e il cavallo. Quattro mosse contro il declino. Laterza, Bari

Rothaermel FT, Thursby M (2005) University-incubator firm knowledge flows: assessing their impact on incubator firm performance. Res Policy 34:305-320

Thune T (2006) Formation of research collaboration between universities and firms: toward an integrated framework of tie formation motives, processes and experiences. Series of Dissertations 8/2006, BI Norwegian School of Management

Varga A (2000) Local academic knowledge transfers and the concentration of economic activity. J Reg Sci 40:289-309 